\title{
PERFORMANCE OF ELITE AROMATIC RICE VARIETIES UNDER DIFFERENT SOWING DATES UNDER EGYPTIAN CONDITION \\ Metwally, T. F. ${ }^{1}$; M. M. El-Malky ${ }^{1}$; A. A. Glelah ${ }^{2}$ and A. S. Gharieb ${ }^{1}$ \\ 1 Rice Research and Training Center, Sakha, Kafr El-sheikh, Egypt \\ 2 Agronomy Dept., Fac. Agric., Kafrelsheikh University, Egypt.
}

\begin{abstract}
Two field experiments were carried out at the farm of Rice Research and Training Center (RRTC), Sakha, Kafr El-Sheikh, Field Crops Research Institute (FCRI), Agricultural Research Center (ARC), Egypt, during 2008 and 2009 seasons, to evaluate some promising aromatic rice varieties (Egyptian Yasmin, IR77510-88-13-3, IR78530-45-3-1-3, IR 74052-177-3-3, IR 71137-51-2 and IR65610-38-2-4-2-6-3) under different sowing dates (April 24 $4^{\text {th }}$, May $10^{\text {th }}$, May $24^{\text {th }}$ and June $10^{\text {th }}$ ). The obtained results showed that rice plants sown on the second date (May $10^{\text {th }}$ ) surpassed those which sown on the late date of sowing (June $10^{\text {th }}$ ) in plant height, leaf area index, dry matter accumulation $\left(\mathrm{g} \mathrm{m}^{-2}\right)$, tillers number $\mathrm{m}^{-2}$, panicle number $\mathrm{m}$ ${ }^{2}$, number of filled grains panicle ${ }^{-1}, 1000$-grain weight, straw yield and grain yield as well as aromatic level in both seasons. There was no significant difference between rice sown on the April $24^{\text {th }}$ or May $10^{\text {th }}$ in the most studied traits. Delay in sowing date significantly increased unfilled grains \%, protein \% and amylose content \% in the two seasons. Aromatic rice varieties varied significantly in most measurements of growth, grain yield and yield attributes, in both seasons. Plants of the Egyptian Yasmin variety having the highest values in the most mentioned traits among the other tested varieties in the two seasons. Plants of Egyptian Yasmin in the two seasons and IR 77510 in the first season produced the greatest grain yield with high aroma level. Plants of IR 65610 variety produced the lowest grain yield in the two seasons. Concerning correlation coefficient among studied characters, grain yield had highly significant positive effect with 1000 grain weight and number of grains per panicle and significant positive with number of panicles $\mathrm{m}^{-2}$. It can be concluded that the optimum sowing date of Egyptian Yasmin variety is April $24^{\text {th }}$ and May $10^{\text {th }}$ while, sowing date of May $10^{\text {th }}$ is the one optimum for IR 77510, IR 78530 and IR 71137. Generally aromatic varieties i.e. Egyptian Yasmin, IR77510-88-1-3-3, IR78530-45-3-1-3, IR 74052-177-3-3, IR 71137-51-2 and IR65610-38-2-4-2-6-3 could be recommended to be sown in April $24^{\text {th }}$ and May $10^{\text {th }}$.
\end{abstract}

\section{INTRODUCTION}

Aromatic rice (scented rice) is one of the main objectives for breeding program in Egypt. Aromatic rice which cultivated mainly in Asia posses high quality and high and high price in comparison with the other rices. In Egypt, aromatic rice is cultivated in small area mainly for export to Arabian countries which prefer this type of rice, moreover, some local consumers prefer it also.

The potentiality of the varieties expressed differently due to planting in different dates (Ganajaxi et al. 2001). Also, optimum planting time is a major factor in rice cultivation and indirectly determines soil temperature and 
weather conditions to which young seedling and rice plants are subjected to it during different developing stages (Ashrafuzzaman et al. 2009). Regarding weather conditions, high temperature, differences between days and night temperature, relative humidity during filling period play an important role to increase aromatic or scent level in the endosperm.

Early planted photoperiod sensitive rice varieties passed lag vegetative phase which increased tallness as well as biomass that tended to lodge during grain filling stage (Akhter et al. 2007)

Genetic diversity can reduce vulnerability to stresses and it constitutes the raw material for plant breeders. Relative divergence measures among accessions can be based on quantitative morphological traits. Genetic relationships among individuals and populations can be measured by similarity of number of quantitative characters (Souza and Sorrells (1991), Zhang et al. (1995), Dinghuhn and Asch (1999), Bahrman et al., (1999) and El-Malky (2004). A better knowledge of the genetic behavior of some aromatic varieties under different sowing dates would help to classify and identify varieties that would be grown successfully under late sowing date.

The objective of the present investigation was to study the optimum planting date and genetic behavior of six aromatic rice varieties under four sowing dates using quantitative characters and asses the correlation coefficients among the studied characters.

\section{MATERIALS AND METHODS}

Two field experiments were carried out at the farm of the Rice Research and Training Center (RRTC), Sakha, Kafr El-Sheikh Field Crops Research Institute (FCRI), Agricultural Research Center (ARC), Egypt, during 2008 and 2009 seasons, to study the performance of some promising aromatic rice varieties under early and late sowing dates. Six aromatic rice varieties namely; IR77510-88-1-3-3, IR78530-45-3-1-3, IR74052-177-3-3, IR71137-51-2 and IR65610-38-2-4-2-6-3 as well as the local variety Egyptian Yasmin were used in the two seasons Table(1). The selected varieties was drawn from introduced materials came from the International Rice Research Institute (IRRI), Los Baños, Philippines.

Table (1): Rice varieties, parentage, origin, type and grain shape.

\begin{tabular}{|l|l|l|l|l|}
\hline \multicolumn{1}{|c|}{ Variety } & \multicolumn{1}{|c|}{ Parentage } & Origin & Type & \multicolumn{1}{c|}{ Grain shape } \\
\hline Egyptian Yasmin & IR262-43-8-11/KDML105 & Egypt & Indica & Long cylinder \\
\hline IR77510-88-1-3-3 & IR68726-3-1-2/IR71137-234-2-2-3-3 & IRRI & Indica & Long cylinder \\
\hline IR78530-45-3-1-3 & $\begin{array}{l}\text { IR69745-251-2-2-1-1/IR71146-287- } \\
3-3-2-1\end{array}$ & IRRI & Indica & Long cylinder \\
\hline IR74052-177-3-3 & $\begin{array}{l}\text { IR44699-21-1-3-4/IR66438-167-3-3- } \\
2-3\end{array}$ & IRRI & Indica & Long cylinder \\
\hline IR71137-51-2 & $\begin{array}{l}\text { IR44699-21-1-3-4/IR66438-167-3-3- } \\
2-3\end{array}$ & IRRI & Indica & Long cylinder \\
\hline IR65610-38-2-4-2-6- & IET10364/IR54950-181-2-1-2-3 & IRRI & Indica & Long cylinder \\
3
\end{tabular}

*IRRI: International Rice Research Institute, Los Baños, Philippines 
Four dates of sowing, i.e. April $24^{\text {th }}$, May $10^{\text {th }}$, May $24^{\text {th }}$ and June $10^{\text {th }}$ were applied in 2008 and 2009 seasons. The six aromatic varieties were laid out in randomized complete block design with four replications in each sowing date in both seasons. A combined analysis was used among sowing dates in each season.

Monthly temperature and relative humidity are shown in Table (2) according to Sakha Meteorological Station.

Table (2): Monthly temperature and relative humidity at Rice Research \& Training Center, Sakha, Kafr El-Sheikh province in 2008 and 2009 rice growing seasons.

\begin{tabular}{|c|c|c|c|c|c|c|}
\hline \multirow{3}{*}{ Month } & \multicolumn{4}{|c|}{ Temperature $\left({ }^{\circ} \mathrm{C}\right)$} & \multirow{2}{*}{\multicolumn{2}{|c|}{ Relative humidity (\%) }} \\
\hline & \multicolumn{2}{|c|}{2008} & \multicolumn{2}{|c|}{2009} & & \\
\hline & Max. & Min. & Max. & Min. & 2008 & 2009 \\
\hline April & 27.8 & 8.3 & 27.0 & 11.0 & 58.0 & 62.5 \\
\hline May & 29.0 & 10.0 & 28.7 & 12.6 & 56.5 & 58.8 \\
\hline June & 33.0 & 15.0 & 33.6 & 19.0 & 66.2 & 62.5 \\
\hline July & 32.0 & 15.7 & 33.0 & 20.2 & 67.8 & 65.3 \\
\hline August & 33.0 & 16.3 & 32.4 & 19.0 & 69.6 & 66.3 \\
\hline September & 33.5 & 15.0 & 32.5 & 19.0 & 62.5 & 61.5 \\
\hline October & 28.0 & 11.0 & 30.3 & 16.2 & 60.0 & 61.8 \\
\hline November & 26.0 & 8.0 & 26.0 & 10.5 & 67.5 & 63.9 \\
\hline
\end{tabular}

The studied characters were leaf area index at 98 days after sowing (DAS), Dry matter accumulation $\left(\mathrm{g} \mathrm{m}^{-2}\right)$ at 98 DAS, plant height $(\mathrm{cm})$ at harvesting, number. of tillers $\mathrm{m}^{-2}, 1000 \mathrm{~g}$ weight, number of filled grains panicle ${ }^{-1}$, number of panicles $\mathrm{m}^{-2}$, straw yield $\left(\mathrm{t} \mathrm{ha}^{-1}\right)$, grain yield $\left(\mathrm{t} \mathrm{ha} \mathrm{a}^{-1}\right)$ and test of aroma.

Test of aroma, there are several ways of testing the aroma of rice varieties. The common one is : place $20-30$ freshly harvested milled rice grains in a $40 \mathrm{ml}$ test tube. Add $20 \mathrm{ml}$ of distilled water, cover with aluminum foil, and place in a bolling water bath for 10 minutes (20 minutes for brown rice). Remove the test tube from the water bath and cool to room temperature. Rate the aroma of rice samples as strong (2), slight (1) and no aroma (0). This method was applied according to standard evaluation system for rice (SES) of IRRI, (1996).

A analysis of variance was carried out as a combined analysis for the four sowing dates in each season according to Gomez and Gomez (1984). Treatment means were compared by Duncan's Multiple Range Test (Duncan, 1955). All statistical analysis was performed using analysis of variance technique by means of "MSTATC" computer software package. The analysis was conducted using the Numerical Taxonomy and Multivariate Analysis system, Version 2.1 (NTSYSpc; Rolhf, 2000). The output was analyzed using an agglomerative hierarchical clustering method with complete linkage strategy. Firstly, the data was subjected to analysis to produce a matrix of dissimilarity values and the phenotypic distance between each pair of varieties was estimated as Euclidean distance. Secondly, cluster analysis was then conducted on the Euclidean distance matrix with un-weighed pairgroup method based on arithmetic average (UPGMA) to develop a dendogram. 


\section{RESULTS AND DISCUSSION}

\section{1- Vegetative characters: \\ 1-1- Leaf area index}

Table (3) showed that leaf area index of aromatic rice at 98 days after sowing (DAS) was significantly affected by sowing date, genotype and their interaction in 2008 and 2009 seasons. Maximum leaf area index was produced by all varieties sown in May $10^{\text {th }}$ which was statistically at par with that in April $24^{\text {th }}$ in the two seasons. Delay sowing date than May $10^{\text {th }}$ resulted in a significant decrease in leaf area index in the two seasons. Minimum leaf area index was recorded at the late sowing date (June $10^{\text {th }}$ ) in both seasons. The increase in leaf area index at early sowing date is caused by an increase in tiller number or leaves on each tiller and in size of successive leaves. These differences between the sowing dates were probably related to differences in weather conditions. These findings agreed with Sahu (1994) and Nayak et al. (2003).

Aromatic rice varieties exhibited significant differences in leaf area index in the two seasons. The rice variety Egyptian Yasmin and IR77510 were among those which having the highest leaf area index. The variety IR65610 produced the lowest leaf area index in both seasons. The superiority of Egyptian Yasmin and IR77510 varieties in leaf area index could be attributed to high number of tillers and leaves. The genotype differences in leaf area index, as here obtained, reflect different genetic make up or genetic constitution. Varietal differences of leaf area index were reported by Ghosh et al. (2004).

Table (3): leaf area index and dry matter accumulation of some aromatic rice varieties at 98 DAS as affected by different sowing dates in 2008 and 2009 rice seasons.

\begin{tabular}{|c|c|c|c|c|}
\hline \multirow{2}{*}{ Factors } & \multicolumn{2}{|c|}{ Leaf Area Index } & \multicolumn{2}{|c|}{ Dry matter accumulation $\left(\mathrm{g} \mathrm{m}^{-2}\right)$} \\
\hline & 2008 & 2009 & 2008 & 2009 \\
\hline Sowing date: & * & ** & $\star \star$ & $\star \star$ \\
\hline April 24 ${ }^{\text {th }}$ & $5.45 a b$ & 5.60ab & $1033 a$ & $1168 a b$ \\
\hline May $10^{\text {th }}$ & $5.86 a$ & $6.07 a$ & $1084 a$ & $1238 a$ \\
\hline May $24^{\text {th }}$ & $5.18 b$ & $5.30 b$ & $991 a b$ & $1099 b$ \\
\hline June $10^{\text {th }}$ & $4.64 c$ & $4.65 c$ & $908 b$ & $968 c$ \\
\hline Variety: & * & ** & ** & * \\
\hline E.Yasmin & $5.507 a b$ & $5.655 a$ & $1039 a$ & $1175 a$ \\
\hline IR77510 & $5.620 a$ & $5.577 a b$ & $1053 a$ & 1159ab \\
\hline IR78530 & $5.200 c$ & $5.515 a b c$ & $991 b$ & $1142 a b$ \\
\hline IR74052 & $5.115 c$ & $5.403 b c$ & $984 b$ & $1127 b$ \\
\hline IR71137 & $5.262 \mathrm{bc}$ & $5.352 c$ & $996 b$ & $1085 c$ \\
\hline IR65610 & $4.997 c$ & $4.925 d$ & $962 c$ & $1022 d$ \\
\hline Interaction & * & ** & $\star \star$ & NS \\
\hline
\end{tabular}

${ }^{*},{ }^{* \star}$ and NS indicate $P<0.05, P<0.01$ and not significant, respectively. Means of each

factor designated by the same letter are not significantly different at $5 \%$ level using Duncan's Multiple Range Test.

The interaction between sowing date and aromatic rice varieties had a significant effect on Leaf area index in the two seasons. Data in Table (4) show that the greatest Leaf area index were produced by the variety 
IR77510 sown in May $10^{\text {th }}$ which was statistically the same to Egyptian Yasmin, IR78530 and IR 71137 sown on the same date in both seasons. The lowest leaf area index was obtained by sowing IR 65610 variety on the late date (June $10^{\text {th }}$ ) in the two seasons. Generally, delaying sowing date decreased leaf area index of all studied varieties in the two seasons. These results in agreement with those reported by Ghosh et al. (2004)

Table (4): Leaf area index at 98 days after sowing as affected by the interaction between sowing date and genotype in 2008 and 2009 seasons.

\begin{tabular}{|c|c|c|c|c|}
\hline \multirow{2}{*}{ Variety } & \multicolumn{4}{|c|}{ Sowing date } \\
\hline & April 24 ${ }^{\text {th }}$ & May $10^{\text {th }}$ & May 24${ }^{\text {th }}$ & June $10^{\text {th }}$ \\
\hline \multicolumn{5}{|c|}{2008 Season } \\
\hline E.Yasmin & 5.660 cde & $6.060 \mathrm{ab}$ & 5.330 efgh & $4.980 \mathrm{hi}$ \\
\hline IR77510 & $5.770 \mathrm{bcd}$ & $6.160 \mathrm{a}$ & 5.570 cde & $4.980 \mathrm{hi}$ \\
\hline IR78530 & $5.160 \mathrm{fghi}$ & $5.850 a b c$ & $5.200 \mathrm{fghi}$ & $4.590 \mathrm{jk}$ \\
\hline IR74052 & 5.420 defg & 5.650 cde & $4.970 \mathrm{hi}$ & $4.420 \mathrm{k}$ \\
\hline IR71137 & 5.530 cdef & $5.810 \mathrm{abc}$ & $5.140 \mathrm{ghi}$ & $4.570 \mathrm{jk}$ \\
\hline IR65610 & $5.170 \mathrm{fghi}$ & 5.640 cde & $4.880 \mathrm{ij}$ & $4.300 \mathrm{k}$ \\
\hline \multicolumn{5}{|c|}{2009 Season } \\
\hline E.Yasmin & $6.230 \mathrm{a}$ & $6.190 \mathrm{a}$ & $5.450 \mathrm{cde}$ & $4.750 \mathrm{fgh}$ \\
\hline IR77510 & $5.940 a b$ & $6.280 \mathrm{a}$ & 5.360 cde & $4.730 \mathrm{fgh}$ \\
\hline IR78530 & $5.980 \mathrm{a}$ & $6.290 \mathrm{a}$ & 5.240 de & $4.550 \mathrm{gh}$ \\
\hline IR74052 & $5.620 \mathrm{bc}$ & $6.020 \mathrm{a}$ & 5.330 cde & $4.640 \mathrm{gh}$ \\
\hline IR71137 & $4.730 \mathrm{fgh}$ & $6.300 \mathrm{a}$ & $5.560 \mathrm{~cd}$ & $4.820 \mathrm{fg}$ \\
\hline IR65610 & 5.090 ef & 5.360 cde & $4.830 \mathrm{fg}$ & $4.420 \mathrm{~h}$ \\
\hline
\end{tabular}

Means of each factor designated by the same letter are not significantly different at $5 \%$ level using Duncan's Multiple Range Test.

\section{1-2- Dry matter accumulation:}

Dry matter accumulation $\left(\mathrm{g} \mathrm{m}^{-2}\right)$ of aromatic rice at 98 DAS as affected by sowing date, genotype and their interaction in 2008 and 2009 seasons are presented in Table (3). Sowing date had a significant effect on dry matter accumulation $\left(\mathrm{g} \mathrm{m}^{-2}\right)$ in the two seasons. Rice plants sown on the second date (May $10^{\text {th }}$ ) significantly accumulated greater dry matter than those sown on the May $24^{\text {th }}$ and June $10^{\text {th }}$ in the two seasons. Such effect of the early sowing might have been resulted from increased photosynthetic area (leaf area), which resulted in more photosynthetic production and consequently increased dry matter accumulation. These findings are true in both seasons and in close agreement with those reported by Vandana et al. (1994), Reddy and Reddy (1994), Nayak et al. (2003) and Latif (2005).

Aromatic rice varieties varied significantly in dry matter accumulation $\left(\mathrm{g} \mathrm{m}^{-2}\right)$ in the two seasons. Plants of the IR77510 variety and Egyptian Yasmin significantly accumulated the greatest dry matter $\left(\mathrm{g} \mathrm{m}^{-2}\right)$ in the two seasons. Plants of IR 65610 variety produced the lowest dry matter accumulation $\left(\mathrm{g} \mathrm{m}^{-2}\right)$ in the two seasons. The superiority of the IR77510 variety and Egyptian Yasmin might have been resulted from increased photosynthetic area (leaf area), which resulted in more photosynthate production and consequently increased dry matter accumulation. Varietal differences of dry matter accumulation were reported by Vandana et al. (1994). 
The interaction between sowing date and aromatic rice varieties had a significant effect on dry matter accumulation $\left(\mathrm{g} \mathrm{m}^{-2}\right)$ at 98 DAS in the first season, (Table 5). The greatest dry matter accumulation $\left(\mathrm{g} \mathrm{m}^{-2}\right)$ was obtained by sowing Egyptian Yasmin variety and IR77510 variety in April 24 $4^{\text {th }}$ or May $10^{\text {th }}$. The lowest dry matter accumulation $\left(\mathrm{g} \mathrm{m}^{-2}\right)$ was obtained by sowing of IR 65610-38-2-4-2-6-3 variety on the late date of sowing. No marked differences of interaction between rice varieties and sowing dates were recorded in the second season.

Table (5): Dry matter accumulation $\left(\mathrm{g} \mathrm{m}^{-2}\right)$ of some aromatic rice varieties as affected by the interaction between sowing date and genotype in 2008 season.

\begin{tabular}{|l|l|l|l|l|}
\hline \multirow{2}{*}{ Variety } & \multicolumn{4}{|c|}{ Sowing date } \\
\cline { 2 - 5 } & April 24$^{\text {th }}$ & May 10 & May 24 $^{\text {th }}$ & June 10 $^{\text {th }}$ \\
\hline E. Yasmin & $1072 \mathrm{ab}$ & $1124 \mathrm{a}$ & $1007 \mathrm{cde}$ & $952 \mathrm{ef}$ \\
IR77510 & $1078 \mathrm{ab}$ & $1127 \mathrm{a}$ & $1046 \mathrm{bcd}$ & $962 \mathrm{ef}$ \\
IR78530 & $990 \mathrm{de}$ & $1078 \mathrm{ab}$ & $992 \mathrm{de}$ & $905 \mathrm{fg}$ \\
IR74052 & $1035 \mathrm{bcd}$ & $1067 \mathrm{abc}$ & $964 \mathrm{ef}$ & $870 \mathrm{~g}$ \\
IR71137 & $1037 \mathrm{bcd}$ & $1051 \mathrm{bcd}$ & $990 \mathrm{de}$ & $906 \mathrm{fg}$ \\
IR65610 & $989 \mathrm{de}$ & $1057 \mathrm{bc}$ & $945 \mathrm{ef}$ & $856 \mathrm{~g}$ \\
\hline
\end{tabular}

Means of each factor designated by the same letter are not significantly different at $5 \%$ level using Duncan's Multiple Range Test.

\section{1-3- Plant height :}

Plant height of aromatic rice at harvest as affected by sowing date, genotype and their interaction in 2008 and 2009 seasons are presented in Table (6). Sowing date significantly influenced plant height in the two seasons. Rice plants which sown on the two early dates April $24^{\text {th }}$ or May $10^{\text {th }}$ were taller than those sown on the two late dates May $24^{\text {th }}$ or June $10^{\text {th }}$ in the two seasons. Delay sowing date decreased plant height in the two seasons. These findings are in close agreement with those reported by Dixit et al. (2004), Akhter et al. (2007) and Ashrafuzzaman et al. (2009).

Table (6): Plant height (cm) and number of tillers $\mathrm{m}^{-2}$ of some aromatic rice varieties at harvest as affected by different sowing dates in 2008 and 2009 rice seasons.

\begin{tabular}{|c|c|c|c|c|}
\hline \multirow{2}{*}{ Factors } & \multicolumn{2}{|c|}{ Plant height (cm) } & \multicolumn{2}{|c|}{ No. of tillers $\mathbf{m}^{-2}$} \\
\hline & 2008 & 2009 & 2008 & 2009 \\
\hline Sowing date: & * & $\star$ & $* *$ & * \\
\hline April 24 & $117.8 \mathrm{a}$ & $109.4 a$ & $413 c$ & $435 b$ \\
\hline May $10^{\text {th }}$ & $112.3 a$ & $109.1 \mathrm{a}$ & $516 a$ & $534 a$ \\
\hline May $24^{\text {th }}$ & $99.70 b$ & $94.90 \mathrm{~b}$ & $472 a b$ & $487 a$ \\
\hline June $10^{\text {th }}$ & $93.40 \mathrm{c}$ & $87.30 \mathrm{c}$ & $432 b c$ & $413 b$ \\
\hline Variety: & * & * & ** & $\star *$ \\
\hline E.Yasmin & $102.7 b$ & $93.30 \mathrm{c}$ & 488ab & $462 \mathrm{bc}$ \\
\hline IR77510 & $101.8 \mathrm{~b}$ & $99.10 \mathrm{bc}$ & $499 a$ & $487 a b$ \\
\hline IR78530 & $109.9 a$ & $101.6 b$ & $470 b$ & $496 a$ \\
\hline IR74052 & $109.9 a$ & $108.6 a$ & $427 c$ & $458 b c$ \\
\hline IR71137 & $112.3 a$ & 103.2ab & $441 c$ & $435 c$ \\
\hline IR65610 & $98.20 \mathrm{~b}$ & $95.30 \mathrm{c}$ & $425 c$ & $466 a b c$ \\
\hline Interaction & $\star \star *$ & * & $\star \star$ & * \\
\hline
\end{tabular}


Aromatic rice varieties revealed a significant difference on plant height in the two seasons. Plants of IR74.52 variety recorded the tallest height in the two seasons. Plants of IR 65610variety recorded the lowest ones in the two seasons.

The interaction between sowing date and aromatic rice varieties had a significant effect on plant height in the two seasons.(Table 7). The tallest plants were obtained by sowing IR74052 and IR71137 varieties on the early date in the two seasons. The shortest plant was obtained by sowing IR 65610 variety on the first date in the second season.

Table (7): Plant height $(\mathrm{cm})$ as affected by the interaction between sowing date and genotype in 2008 and 2009 seasons.

\begin{tabular}{|c|c|c|c|c|}
\hline \multirow{2}{*}{ Variety } & \multicolumn{4}{|c|}{ Sowing date } \\
\hline & April 24 ${ }^{\text {th }}$ & May $10^{\text {th }}$ & May 24${ }^{\text {th }}$ & June $10^{\text {th }}$ \\
\hline \multicolumn{5}{|c|}{2008 Season } \\
\hline E.Yasmin & 113.0 cde & 110.0 defg & $94.00 \mathrm{i}$ & $93.90 \mathrm{i}$ \\
\hline IR77510 & 112.1 cdef & $103.2 \mathrm{gh}$ & $98.10 \mathrm{hi}$ & $93.70 \mathrm{i}$ \\
\hline IR78530 & 111.2 cdef & $119.7 b$ & $105.3 \mathrm{fg}$ & $103.4 \mathrm{gh}$ \\
\hline IR74052 & $134.8 \mathrm{a}$ & $117.2 \mathrm{bc}$ & $94.40 \mathrm{i}$ & $93.30 \mathrm{i}$ \\
\hline IR71137 & $129.2 \mathrm{a}$ & $115.2 \mathrm{bcd}$ & 112.2 cdef & $92.50 \mathrm{i}$ \\
\hline IR65610 & $106.6 \mathrm{efg}$ & $108.3 \mathrm{defg}$ & $94.40 \mathrm{i}$ & $83.50 \mathrm{~J}$ \\
\hline \multicolumn{5}{|c|}{2009 Season } \\
\hline E.Yasmin & 105.7 def & $101.7 \mathrm{fg}$ & $90.10 \mathrm{~h}$ & $75.60 \mathrm{i}$ \\
\hline IR77510 & $110.6 \mathrm{bcd}$ & 102.8 ef & $94.30 \mathrm{~h}$ & $88.70 \mathrm{~h}$ \\
\hline IR78530 & 109.7 b-e & $106.5 c-f$ & $95.50 \mathrm{gh}$ & $94.70 \mathrm{~h}$ \\
\hline IR74052 & $116.4 \mathrm{ab}$ & $119.1 \mathrm{a}$ & 104.4 def & $94.50 \mathrm{~h}$ \\
\hline IR71137 & $112.7 \mathrm{abc}$ & $116.2 \mathrm{ab}$ & $94.60 \mathrm{~h}$ & $89.50 \mathrm{~h}$ \\
\hline IR65610 & $101.2 \mathrm{fg}$ & 108.2 cdef & $90.70 \mathrm{~h}$ & $80.80 \mathrm{i}$ \\
\hline
\end{tabular}

Means of each factor designated by the same letter are not significantly different at $5 \%$ level using Duncan's Multiple Range Test.

\section{1-4- Number of tillers $\mathrm{m}^{-2}$ :}

Tillers numbers $\mathrm{m}^{-2}$ of aromatic rice at harvest as affected by sowing date, genotype and their interaction in 2008 and 2009 seasons are presented in Table (6). Sowing date substantially influenced tillers numbers $\mathrm{m}^{-2}$ at dates in the two seasons. Rice plants sown on the second or third dates produced greater tillers numbers $\mathrm{m}^{-2}$ than those sown on early and late dates in the two seasons. These finding are supported by the work done by Aslam (2000), Dixit et al. (2004), Akram et al. (2007), Shahidullah at al. (2009) and Mannan et al. (2009).

Aromatic rice varieties significantly varied in tillers numbers $\mathrm{m}^{-2}$ in the two seasons. Plants of IR77510 variety produced the greatest tillers numbers $\mathrm{m}^{-2}$ at harvest in the two seasons. Plants of IR 65610 and IR 71137 varieties produced the lowest tillers numbers $\mathrm{m}^{-2}$ in the first and second seasons, respectively.

The interaction between sowing date and aromatic rice varieties had a significant effect on tillers numbers $\mathrm{m}^{-2}$ in the two seasons (Table 8). The greatest tillers numbers $\mathrm{m}^{-2}$ was obtained by sowing IR77510 variety on the second date in the two seasons. The lowest tillers numbers $\mathrm{m}^{-2}$ were obtained by sowing IR65610 variety on the late date in the two seasons. 
Table (8): Number of tillers $\mathrm{m}^{-2}$ of some aromatic rice varieties as affected by the interaction between sowing date and genotype in 2008 and 2009 seasons.

\begin{tabular}{|c|c|c|c|c|}
\hline \multirow{2}{*}{ Variety } & \multicolumn{4}{|c|}{ Sowing date } \\
\hline & April 24${ }^{\text {th }}$ & May $10^{\text {th }}$ & May $24^{\text {th }}$ & June $10^{\text {th }}$ \\
\hline \multicolumn{5}{|c|}{2008 Season } \\
\hline E.Yasmin & $451.0 \mathrm{f}-\mathrm{J}$ & 526.0 a-d & $491.0 \mathrm{~b}-\mathrm{g}$ & 482.0 c-h \\
\hline IR77510 & $436.0 \mathrm{~g}-\mathrm{k}$ & $556.0 \mathrm{a}$ & $542.0 \mathrm{ab}$ & $463.0 \mathrm{e}-\mathrm{i}$ \\
\hline IR78530 & $396.0 \mathrm{Jk}$ & $536.0 \mathrm{abc}$ & 510.0 a-e & $438.0 \mathrm{~g}-\mathrm{k}$ \\
\hline IR74052 & $398.0 \mathrm{Jk}$ & $474.0 \mathrm{~d}-\mathrm{i}$ & $437.0 \mathrm{~g}-\mathrm{k}$ & $399.0 \mathrm{Jk}$ \\
\hline IR71137 & $405.0 \mathrm{Jk}$ & 503.0 a-f & $428.0 \mathrm{~h}-\mathrm{k}$ & $427.0 \mathrm{~h}-\mathrm{k}$ \\
\hline IR65610 & $391.0 \mathrm{k}$ & 500.0 b-f & $424.0 \mathrm{iJk}$ & $385.0 \mathrm{k}$ \\
\hline \multicolumn{5}{|c|}{2009 Season } \\
\hline E.Yasmin & $488.0 \mathrm{~d}-\mathrm{g}$ & 518.0 a-e & $460.0 \mathrm{f}-\mathrm{i}$ & $382.0 \mathrm{k}$ \\
\hline IR77510 & $463.0 \mathrm{e}-\mathrm{i}$ & 541.0 a-d & 514.0 a-f & $429.0 \mathrm{~h}-\mathrm{k}$ \\
\hline IR78530 & 511.0 a-f & $558.0 \mathrm{a}$ & 504.0 a-f & 412.0 iJk \\
\hline IR74052 & $393.0 \mathrm{Jk}$ & $544.0 \mathrm{abc}$ & $490.0 \mathrm{c}-\mathrm{g}$ & $403.0 \mathrm{Jk}$ \\
\hline IR71137 & 314.01 & $546.0 \mathrm{ab}$ & 474.0 e-h & $405.0 \mathrm{Jk}$ \\
\hline IR65610 & $442.0 \mathrm{~g}-\mathrm{J}$ & $495.0 \mathrm{~b}-\mathrm{g}$ & 483.0 e-h & $445.0 \mathrm{~g}-\mathrm{J}$ \\
\hline
\end{tabular}

Means of each factor designated by the same letter are not significantly different at $5 \%$ level using Duncan's Multiple Range Test.

\section{1-5- 1000 - grain weight $(g)$ :}

1000 -grain weight of aromatic rice as affected by sowing date, genotype and their interaction in 2008 and 2009 seasons are presented in Table (9). Sowing date substantially influenced 1000-grain weight in the two seasons. Rice plants sown in April $24^{\text {th }}$ and May $10^{\text {th }}$ significantly produced heavier 1000-grain weight than those sown in June $24^{\text {th }}$ in the two seasons. Delay sowing date significantly decreased 1000-grain weight in the two seasons. Such effect of the early date might have been resulted from increased photosynthetic area (leaf area), which resulted in more photosynthetic production and consequently increased dry matter accumulation and grain felling. Similar trend was found by Lu-Kaiyang and Cai-Mingli (2000), Singh et al. (2004), Shah and Kaliash (2005), Akram et al. (2007) and Nahar et al. (2009).

Aromatic rice varieties exhibited significant differences in 1000-grain weight in the two seasons. The relative ranking of varieties with respect to 1000 -grain weight was inconsistent in the two seasons. The Egyptian Yasmin variety and IR 65610 and IR 78530 varieties were among those having the heaviest 1000-grain weight in both seasons. Mondal et al. (2005) studied 17 modern cultivars of transplanted rice and reported that 1000-grain weight differed significantly among the studied cultivars, which supported the present study results.

The interaction between sowing date and aromatic rice varieties had a significant effect on 1000-grain weight in the two seasons (Table 10). The relative ranking of interaction with respect to 1000-grain weight was inconsistent in the two seasons. The Egyptian Yasmin, IR 78530 and IR 65610 varieties sown on $24^{\text {th }}$ April or $10^{\text {th }}$ May were among those having the heaviest 1000-grain weight in both seasons. Also, IR 77510 and IR 71137 varieties sown in May $10^{\text {th }}$ did not differ from the mentioned varieties in this respect in the two seasons. 
Table (9): $1000 \mathrm{~g}$ weight, No. of filled grains panicle ${ }^{-1}$ and No. of panicles $\mathrm{m}^{-2}$ of some aromatic rice varieties as affected by sowing dates in 2008 and 2009 seasons.

\begin{tabular}{|c|c|c|c|c|c|c|}
\hline \multirow[t]{2}{*}{ Factors } & \multicolumn{2}{|c|}{$1000 \mathrm{~g}$ weight } & \multicolumn{2}{|c|}{$\begin{array}{l}\text { No of filled grains } \\
\text { panicle }^{-1}\end{array}$} & \multicolumn{2}{|c|}{ No. of Panicles $\mathrm{m}^{-2}$} \\
\hline & 2008 & 2009 & 2008 & 2009 & 2008 & 2009 \\
\hline Sowing date: & $* *$ & * & $\star \star$ & $\star *$ & $\star \star$ & $* *$ \\
\hline April 24 ${ }^{\text {th }}$ & $24.064 a$ & $23.989 a$ & $145 a$ & $144 a$ & $406 b$ & $420 b$ \\
\hline May $10^{\text {th }}$ & $24.080 a$ & $24.211 a$ & $134 a b$ & $130 a b$ & $507 a$ & $514 a$ \\
\hline May $24^{\text {th }}$ & $23.532 b$ & $23.213 b$ & $117 \mathrm{bc}$ & $123 b c$ & $468 a$ & $472 a$ \\
\hline June $10^{\text {th }}$ & $21.618 \mathrm{~b}$ & $21.929 c$ & $101 c$ & $113 c$ & $417 \mathrm{~b}$ & $400 \mathrm{~b}$ \\
\hline Variety : & * & * & ** & ** & ** & * \\
\hline E.Yasmin & $24.00 \mathrm{a}$ & $23.87 a$ & $141 \mathrm{a}$ & $147 a$ & $482 a$ & $441 b c$ \\
\hline IR77510 & $23.10 \mathrm{bc}$ & 23.16ab & $134 a b$ & $117 \mathrm{~b}$ & $489 a$ & $471 a b$ \\
\hline IR78530 & $23.92 a$ & $23.76 \mathrm{a}$ & $120 c$ & $129 b$ & $462 a b$ & $484 a$ \\
\hline IR74052 & $22.52 \mathrm{c}$ & $22.83 b$ & $121 \mathrm{c}$ & $129 b$ & $419 c$ & $441 \mathrm{bc}$ \\
\hline IR71137 & $22.75 c$ & 23.12ab & $130 \mathrm{bc}$ & $127 b$ & $429 b c$ & $420 c$ \\
\hline IR65610 & $23.64 a b$ & 23.27ab & $100 d$ & $117 \mathrm{~b}$ & $416 c$ & $452 b c$ \\
\hline Interaction & * & * & * & * & $\star \star$ & $\star$ \\
\hline
\end{tabular}

${ }^{*},{ }^{* \star}$ and NS indicate $P<0.05, P<0.01$ and not significant, respectively. Means of each factor designated by the same letter are not significantly different at $5 \%$ level using Duncan's Multiple Range Test

Table (10): 1000-grain weight $(\mathrm{g})$ of some aromatic rice varieties as affected by the interaction between sowing date and genotype in 2008 and 2009 seasons.

\begin{tabular}{|c|c|c|c|c|}
\hline \multirow{2}{*}{ Variety } & \multicolumn{4}{|c|}{ Sowing date } \\
\hline & April 24 ${ }^{\text {th }}$ & May $10^{\text {th }}$ & May 24 ${ }^{\text {th }}$ & June $10^{\text {th }}$ \\
\hline \multicolumn{5}{|c|}{2008 Season } \\
\hline E.Yasmin & $24.99 \mathrm{a}$ & 24.19 a-d & $24.05 \mathrm{a}-\mathrm{e}$ & $22.79 \mathrm{fg}$ \\
\hline IR77510 & $23.23 c-g$ & $23.92 \mathrm{a}-\mathrm{f}$ & 23.88 a-f & $21.39 \mathrm{~h}$ \\
\hline IR78530 & $24.88 a b$ & $24.35 a b c$ & $23.82 b-f$ & $22.64 \mathrm{~g}$ \\
\hline IR74052 & $23.47 \mathrm{c}-\mathrm{g}$ & $22.96 \mathrm{efg}$ & $22.86 \mathrm{fg}$ & $20.80 \mathrm{~h}$ \\
\hline IR71137 & 23.03 efg & 24.25 a-d & $23.13 \mathrm{~d}-\mathrm{g}$ & $20.59 h$ \\
\hline IR65610 & $24.79 a b$ & $24.82 a b$ & $23.45 \mathrm{~cd}-\mathrm{g}$ & $21.51 \mathrm{~h}$ \\
\hline \multicolumn{5}{|c|}{2009 Season } \\
\hline E.Yasmin & 24.32 a-d & 23.94 a-d & $24.39 \mathrm{abc}$ & $22.82 \mathrm{efg}$ \\
\hline IR77510 & 21.60 hiJ & $24.73 \mathrm{a}$ & $24.34 \mathrm{a}-\mathrm{d}$ & $21.98 \mathrm{ghi}$ \\
\hline IR78530 & $25.01 \mathrm{a}$ & 24.25 a-d & $22.47 \mathrm{fgh}$ & 23.31 cdef \\
\hline IR74052 & 24.05 a-d & 23.24 def & 23.31 cdef & $20.70 \mathrm{~J}$ \\
\hline IR71137 & $24.53 a b$ & $24.60 a b$ & $21.19 \mathrm{iJ}$ & 22.17 ghi \\
\hline IR65610 & $24.43 \mathrm{ab}$ & $24.50 \mathrm{ab}$ & 23.58 b-e & $20.59 \mathrm{~J}$ \\
\hline
\end{tabular}

Means of each factor designated by the same letter are not significantly different at $5 \%$ level using Duncan's Multiple Range Test.

\section{1-6- Number of filled grains per panicle:}

Number of filled grains per panicle of aromatic rice as affected by sowing date, genotype and their interaction in 2008 and 2009 seasons are presented in Table (9). Sowing date substantially influenced number of filled grains per panicle in the two seasons. Rice plants sown on the first and second dates significantly produced greater number of filled grains per panicle than those sown on the late date in the two seasons. These finding are supported by the work done by Mahmood et al. (1995), Singh et al. (2004), Shah and Bhurer (2005) and Nahar et al. (2009). 
Aromatic rice varieties significantly varied in number of filled grains per panicle in the two seasons. Plants of IR77510 variety produced the highest number of filled grains per panicle at harvest in the two seasons. Plants of IR 65610 variety produced the lowest number of filled grains per panicle in the first and second seasons, respectively.

The interaction between sowing date and aromatic rice varieties had a significant effect on number of filled grains per panicle in the two seasons (Table 11). The greatest number of grains per panicle was obtained by sowing Egyptian Yasmin variety on the April $24^{\text {th }}$ in the two seasons. The lowest number of filled grains per panicle were obtained by sowing IR 65610 variety on the late date in the two seasons.

Table (11): No. of filled grains panicle ${ }^{-1}$ of some aromatic rice varieties as affected by the interaction between sowing date and genotype in 2008 and 2009 seasons.

\begin{tabular}{|c|c|c|c|c|}
\hline \multirow{2}{*}{ Variety } & \multicolumn{4}{|c|}{ Sowing date } \\
\hline & April 24${ }^{\text {th }}$ & May $10^{\text {th }}$ & May $24^{\text {th }}$ & June $10^{\text {th }}$ \\
\hline \multicolumn{5}{|c|}{2008 Season } \\
\hline $\begin{array}{l}\text { E.Yasmin } \\
\text { IR77510 } \\
\text { IR78530 } \\
\text { IR74052 } \\
\text { IR71137 } \\
\text { IR65610 } \\
\end{array}$ & $\begin{array}{c}161.0 \mathrm{a} \\
154.0 \mathrm{ab} \\
137.0 \mathrm{cde} \\
138.0 \mathrm{cde} \\
151.0 \mathrm{abc} \\
129.0 \mathrm{defg}\end{array}$ & $\begin{array}{c}151.0 \mathrm{abc} \\
143.0 \mathrm{bcd} \\
126.0 \mathrm{efg} \\
125.0 \mathrm{efg} \\
139.0 \mathrm{cde} \\
118.0 \mathrm{f}-\mathrm{J}\end{array}$ & $\begin{array}{c}129.0 \text { defg } \\
131.0 \text { def } \\
120.0 \mathrm{f}-\mathrm{iJ} \\
115.0 \mathrm{ghiJ} \\
122.0 \mathrm{fgh} \\
85.00 \mathrm{l}\end{array}$ & $\begin{array}{c}121.0 \mathrm{fghi} \\
109.0 \mathrm{hiJk} \\
97.00 \mathrm{kl} \\
107.0 \mathrm{iJk} \\
106.0 \mathrm{Jk} \\
66.00 \mathrm{~m} \\
\end{array}$ \\
\hline \multicolumn{5}{|c|}{2009 Season } \\
\hline $\begin{array}{l}\text { E.Yasmin } \\
\text { IR77510 } \\
\text { IR78530 } \\
\text { IR74052 } \\
\text { IR71137 } \\
\text { IR65610 } \\
\end{array}$ & $\begin{array}{c}161.0 \mathrm{a} \\
140.0 \mathrm{cde} \\
142.0 \mathrm{~cd} \\
151.0 \mathrm{~b} \\
134.0 \mathrm{defg} \\
137.0 \mathrm{def}\end{array}$ & $\begin{array}{c}146.0 \mathrm{bc} \\
112.0 \mathrm{kl} \\
126.0 \mathrm{ghiJ} \\
133.0 \mathrm{~d}-\mathrm{h} \\
129.0 \mathrm{fghi} \\
134.0 \mathrm{defg}\end{array}$ & $\begin{array}{c}148.0 \mathrm{bc} \\
109.0 \mathrm{l} \\
124.0 \mathrm{hiJ} \\
119.0 \mathrm{Jk} \\
132.0 \mathrm{e}-\mathrm{i} \\
107.0 \mathrm{l}\end{array}$ & $\begin{array}{c}133.0 \mathrm{~d}-\mathrm{h} \\
105.0 \mathrm{l} \\
123.0 \mathrm{iJ} \\
112.0 \mathrm{kl} \\
113.0 \mathrm{kl} \\
89.00 \mathrm{~m}\end{array}$ \\
\hline
\end{tabular}

Means of each factor designated by the same letter are not significantly different at $5 \%$ level using Duncan's Multiple Range Test.

\section{1-7- Number of panicle $\mathrm{m}^{-2}$ :}

Panicle number $\mathrm{m}^{-2}$ of aromatic rice as affected by sowing date, genotype and their interaction in 2008 and 2009 seasons are presented in Table (9). Sowing date substantially influenced panicle number $\mathrm{m}^{-2}$ in the two seasons. Rice plants sown on the second or third dates significantly produced greater panicle number $\mathrm{m}^{-2}$ than those sown on early and late dates in the two seasons. These findings are consistent with those reported by Lee and Jun (1998), Ganajaxi et al. (2001), Linscombe et al. (2004), Singh et al. (2004), Nahar et al. (2009) and Mannan et al. (2009).

Aromatic rice varieties significantly varied in panicle number $\mathrm{m}^{-2}$ in the two seasons. Plants of IR77510 variety markedly produced the highest panicle number $\mathrm{m}^{-2}$ at harvest in the two seasons. Plants of IR 65610 and IR 71137 varieties produced the lowest panicle number $\mathrm{m}^{-2}$ in the first and second seasons, respectively. The increase in panicle number $\mathrm{m}^{-2}$ may be due to increase in tillers number $\mathrm{m}^{-2}$.

The interaction between sowing date and aromatic rice varieties had a significant effect on panicle number $\mathrm{m}^{-2}$ in the two seasons.(Table 12). The 
greatest panicle number $\mathrm{m}^{-2}$ was obtained by sowing IR77510 variety on the second date in the two seasons. The lowest panicle number $\mathrm{m}^{-2}$ were obtained by sowing IR 65610 and Egyptian Yasmin varieties on the late date in the first and second seasons, respectively.

Table (12): No. of panicle $\mathrm{m}^{2}$ of some aromatic rice varieties as affected by the interaction between sowing date and genotype in 2008 and 2009 seasons.

\begin{tabular}{|c|c|c|c|c|}
\hline \multirow{2}{*}{ Variety } & \multicolumn{4}{|c|}{ Sowing date } \\
\hline & April 24 ${ }^{\text {th }}$ & May $10^{\text {th }}$ & May 24 ${ }^{\text {th }}$ & June $10^{\text {th }}$ \\
\hline \multicolumn{5}{|c|}{2008 Season } \\
\hline E.Yasmin & 439.0 ghi & $523.0 \mathrm{abc}$ & 489.0 cde & 476.0 defg \\
\hline IR77510 & 431.0 hiJ & $550.0 \mathrm{a}$ & $531.0 \mathrm{ab}$ & $443.0 \mathrm{fghi}$ \\
\hline IR78530 & $393.0 \mathrm{Jkl}$ & $532.0 \mathrm{ab}$ & $506.0 \mathrm{bcd}$ & $418.0 \mathrm{iJk}$ \\
\hline IR74052 & $392.0 \mathrm{Jkl}$ & 464.0 efgh & $435.0 \mathrm{hi}$ & $386.0 \mathrm{kl}$ \\
\hline IR71137 & $395.0 \mathrm{Jkl}$ & 490.0 cde & 426.0 hiJk & $407.0 \mathrm{iJkl}$ \\
\hline IR65610 & $389.0 \mathrm{kl}$ & 480.0 def & $422.0 \mathrm{iJk}$ & 371.01 \\
\hline \multicolumn{5}{|c|}{2009 Season } \\
\hline E.Yasmin & 470.0 defg & $496.0 \mathrm{bcd}$ & 434.0 fghi & 363.01 \\
\hline IR77510 & 446.0 e-h & $521.0 \mathrm{abc}$ & $503.0 \mathrm{a}-\mathrm{d}$ & 415.0 h-k \\
\hline IR78530 & 501.0 a-d & $545.0 \mathrm{a}$ & $489.0 \mathrm{~b}-\mathrm{e}$ & $399.0 \mathrm{iJkl}$ \\
\hline IR74052 & $373.0 \mathrm{kl}$ & $525.0 \mathrm{ab}$ & 477.0 cdef & $388.0 \mathrm{Jkl}$ \\
\hline IR71137 & $302.0 \mathrm{~m}$ & $520.0 \mathrm{abc}$ & 465.0 defg & $393.0 \mathrm{iJkl}$ \\
\hline IR65610 & 426.0 ghiJ & 479.0 cdef & 461.0 defg & $443.0 \mathrm{fgh}$ \\
\hline
\end{tabular}

Means of each factor designated by the same letter are not significantly different at $5 \%$ level using Duncan's Multiple Range Test.

\section{1-8- Straw yield ( $\left.\mathrm{t} \mathrm{ha}^{-1}\right)$ :}

Straw yield of aromatic rice as affected by sowing date, genotype and their interaction in 2008 and 2009 seasons are presented in Table (13). Sowing date substantially influenced straw yield in the two seasons. Rice plants sown in April $24^{\text {th }}$ and May $10^{\text {th }}$ markedly produced higher straw yield than those sown on the late date in both season. Delay sowing date decreased straw yield in the two seasons. Thus, the two early sowing date increased straw yield through increasing number of tillers $\mathrm{m}^{-2}$ and plant height. Moreover, growth in terms of leaf area index, dry matter accumulation and crop growth rate were in favour of the early dates and in turn increased different straw yield. Aslam (2000) and Islam et al. (2008) reported similar trend.

Aromatic rice varieties exerted a significant effect on straw yield in the two seasons. Plants of Egyptian Yasmin and IR 77510 in markedly produced the highest straw yield in the two seasons. Plants of IR65610 variety produced the lowest straw yield in the two seasons. The superiority of Egyptian Yasmin and IR 77510 variety might resulted from its better growth. Ashrafuzzaman et al. (2009) indicated that six aromatic rice varieties differed significantly to straw yield. 
Table (13): Straw yield and grain yield and of some aromatic rice varieties as affected by sowing dates in 2008 and 2009 seasons.

\begin{tabular}{|c|c|c|c|c|}
\hline \multirow{2}{*}{ Factor } & \multicolumn{2}{|c|}{ Straw yield (t ha-1) } & \multicolumn{2}{|c|}{ Grain yield (t ha-1) } \\
\hline & 2008 & 2009 & 2008 & 2009 \\
\hline Sowing date: & ** & * & $\star \star$ & ** \\
\hline April $24^{\text {th }}$ & $12.388 \mathrm{a}$ & $12.092 \mathrm{a}$ & $7.295 \mathrm{a}$ & $7.984 \mathrm{~b}$ \\
\hline May $10^{\text {th }}$ & $12.279 \mathrm{a}$ & $11.362 \mathrm{a}$ & $7.689 \mathrm{a}$ & $9.021 \mathrm{a}$ \\
\hline May $24^{\text {th }}$ & $11.909 \mathrm{a}$ & $9.862 \mathrm{~b}$ & $5.911 \mathrm{~b}$ & $7.384 \mathrm{c}$ \\
\hline June $10^{\text {th }}$ & $9.977 \mathrm{~b}$ & $9.507 \mathrm{~b}$ & $5.411 \mathrm{~b}$ & $6.019 \mathrm{~d}$ \\
\hline Variety : & * & * & ** & * \\
\hline E.Yasmin & $11.79 \mathrm{ab}$ & $11.23 \mathrm{a}$ & $7.134 \mathrm{a}$ & $9.180 \mathrm{a}$ \\
\hline IR77510 & $12.72 \mathrm{a}$ & $10.93 \mathrm{a}$ & $7.067 \mathrm{ab}$ & $8.019 \mathrm{~b}$ \\
\hline IR78530 & $10.71 b$ & $11.18 \mathrm{a}$ & $6.259 \mathrm{c}$ & $7.103 \mathrm{bc}$ \\
\hline IR74052 & $11.60 \mathrm{~b}$ & $11.38 \mathrm{a}$ & $6.183 \mathrm{c}$ & $6.921 \mathrm{bc}$ \\
\hline IR71137 & $11.75 \mathrm{ab}$ & $11.06 \mathrm{a}$ & $6.483 \mathrm{bc}$ & $7.644 \mathrm{bc}$ \\
\hline IR65610 & $11.26 \mathrm{~b}$ & $8.466 \mathrm{~b}$ & $6.334 \mathrm{c}$ & $6.747 \mathrm{c}$ \\
\hline Interaction & * & * & ** & ** \\
\hline
\end{tabular}

${ }^{*},{ }^{* *}$ and NS indicate $P<0.05, P<0.01$ and not significant, respectively. Means of each factor designated by the same letter are not significantly different at $5 \%$ level using Duncan's Multiple Range Test.

The interaction between sowing date and aromatic rice varieties had a significant effect on straw yield in the two seasons (Table 14). The highest straw yield was obtained by sowing Egyptian Yasmin variety and IR 77510 varieties sown in April $24^{\text {th }}$ and May $10^{\text {th }}$ during the two seasons. Delay sowing date decreased straw yield of all varieties in the two seasons.

Table (14): Straw yield $\left(t_{\text {ha- }}^{-1}\right)$ of some aromatic rice varieties as affected by the interaction between sowing date and genotype in 2008 and 2009 seasons.

\begin{tabular}{|c|c|c|c|c|}
\hline \multirow{2}{*}{ Variety } & \multicolumn{4}{|c|}{ Sowing date } \\
\hline & April 24${ }^{\text {th }}$ & May $10^{\text {th }}$ & May $24^{\text {th }}$ & June $10^{\text {th }}$ \\
\hline \multicolumn{5}{|c|}{2008 Season } \\
\hline E.Yasmin & $12.91 \mathrm{abc}$ & $12.25 \mathrm{abc}$ & $11.95 \mathrm{a}-\mathrm{d}$ & 10.04 e-h \\
\hline IR77510 & $13.31 \mathrm{a}$ & $13.16 \mathrm{ab}$ & $12.90 \mathrm{abc}$ & $11.50 \mathrm{a}-\mathrm{e}$ \\
\hline IR78530 & 11.15 cdef & $11.05 c-g$ & $11.30 \mathrm{~b}-\mathrm{f}$ & $9.341 \mathrm{gh}$ \\
\hline IR74052 & $12.56 \mathrm{abc}$ & $12.81 \mathrm{abc}$ & $11.95 \mathrm{a}-\mathrm{d}$ & $9.090 \mathrm{~h}$ \\
\hline IR71137 & $12.45 \mathrm{abc}$ & $12.25 a b c$ & $11.95 \mathrm{a}-\mathrm{d}$ & $10.35 d-h$ \\
\hline IR65610 & $11.95 \mathrm{a}-\mathrm{d}$ & $12.15 \mathrm{a}-\mathrm{d}$ & $11.40 \mathrm{~b}-\mathrm{e}$ & $9.542 \mathrm{fgh}$ \\
\hline \multicolumn{5}{|c|}{2009 Season } \\
\hline E.Yasmin & $13.03 \mathrm{ab}$ & $11.83 \mathrm{~b}-\mathrm{e}$ & $10.14 \mathrm{~d}-\mathrm{h}$ & $9.894 \mathrm{e}-\mathrm{i}$ \\
\hline IR77510 & $12.90 \mathrm{ab}$ & $12.30 a b c$ & $9.023 \mathrm{ghi}$ & 9.499 fghi \\
\hline IR78530 & $13.97 \mathrm{a}$ & $12.48 a b c$ & $9.326 \mathrm{ghi}$ & $8.930 \mathrm{ghi}$ \\
\hline IR74052 & $13.34 \mathrm{ab}$ & $11.49 \mathrm{~b}-\mathrm{f}$ & $10.58 \mathrm{c}-\mathrm{g}$ & $10.11 \mathrm{~d}-\mathrm{i}$ \\
\hline IR71137 & $10.02 \mathrm{~d}-\mathrm{i}$ & $11.69 \mathrm{~b}-\mathrm{e}$ & $11.98 \mathrm{bcd}$ & $10.54 \mathrm{c}-\mathrm{g}$ \\
\hline IR65610 & $9.289 \mathrm{ghi}$ & $8.376 \mathrm{hi}$ & $8.128 \mathrm{hi}$ & $8.069 \mathrm{i}$ \\
\hline
\end{tabular}

Means of each factor designated by the same letter are not significantly different at $5 \%$ level using Duncan's Multiple Range Test.

\section{1-9- Grain yield $\left(\mathrm{t} \mathrm{ha}^{-1}\right)$ :}

Grain yield is the final indicator of crop behavior under different crop management practices. Grain yield of aromatic rice as affected by sowing date, genotype and their interaction in 2008 and 2009 seasons are presented 
in Table (13). Sowing date substantially influenced grain yield in the two seasons. Rice plants sown in May $10^{\text {th }}$ significantly out yielded those sown on the other dates in both season, except the early date April $24^{\text {th }}$ in the first season. Delay sowing date decreased grain yield in the two seasons. Thus, the two early sowing date increased grain yield through increasing number of panicles $\mathrm{m}^{-2}$ and 1000-grains weight. Moreover, growth in terms of leaf area index, dry matter accumulation and crop growth rate were in favour of the early dates and in turn increased different yield attributes. Similar conclusion was previously drawn by Nayak et al. (2003), Verma et al. (2004), Shah and Kaliash (2005), Habibullah et al. (2007), Hossain et al. (2008), Safdar et al. (2008) and Nahar et. al (2009).

Aromatic rice varieties exerted a significant effect on grain yield in the two seasons. Plants of Egyptian Yasmin in the two seasons and IR 77510 in the first season significantly produced the greatest grain yield. Plants of IR 65610 variety produced the lowest grain yield in the two seasons. The superiority of Egyptian Yasmin and IR 77510 variety might resulted from its better growth, i.e. leaf area index, dry matter accumulation and yield attributes, i.e. number of panicles $\mathrm{m}^{-2}$ and number of filled grain panicle ${ }^{-1}$. Ganajaxi et al. (2001), Ghosh et al. (2004) Ashrafuzzaman et al. (2009), Mannan et al. (2009) and Shahidullah et al. (2009) reported similar results for aromatic rice genotypic variations for grain yield.

The interaction between sowing date and aromatic rice varieties had a significant effect on grain yield in the two seasons (Table 15 ). The highest grain yield was obtained by sowing Egyptian Yasmin variety, IR 77510, IR 78530 and IR 71137 varieties on $10^{\text {th }}$ May in the two seasons. The Egyptian Yasmin variety sown on April $24^{\text {th }}$ or May $10^{\text {th }}$ produced the same grain yield in the two seasons. Delay sowing date decreased grain yield of all varieties in the two seasons.

Table (15): Grain yield $\left(\mathrm{t} \mathrm{ha}^{-1}\right)$ of some aromatic rice varieties as affected by the interaction between sowing date and genotype in 2008 and 2009 seasons.

\begin{tabular}{|c|c|c|c|c|}
\hline \multirow{2}{*}{ Variety } & \multicolumn{4}{|c|}{ Sowing date } \\
\hline & April 24${ }^{\text {th }}$ & May $10^{\text {th }}$ & May 24 ${ }^{\text {th }}$ & June $10^{\text {th }}$ \\
\hline \multicolumn{5}{|c|}{2008 Season } \\
\hline E.Yasmin & $7.600 \mathrm{a}-\mathrm{d}$ & $8.467 \mathrm{a}$ & 6.467 efgh & 6.000 ghiJ \\
\hline IR77510 & $8.133 a b c$ & $8.267 a b$ & 6.133 fghi & $5.733 \mathrm{hiJ}$ \\
\hline IR78530 & 7.102 cdef & $7.533 \mathrm{a}-\mathrm{d}$ & $5.400 \mathrm{iJ}$ & $5.000 \mathrm{~J}$ \\
\hline IR74052 & $6.600 \mathrm{~d}-\mathrm{h}$ & 7.000 defg & 5.733 hiJ & $5.400 \mathrm{iJ}$ \\
\hline IR71137 & $7.333 \mathrm{~b}-\mathrm{e}$ & $7.600 \mathrm{a}-\mathrm{d}$ & 5.933 hiJ & $5.067 \mathrm{iJ}$ \\
\hline IR65610 & $7.000 \mathrm{~d}-\mathrm{g}$ & $7.267 \mathrm{~b}-\mathrm{e}$ & 5.800 hiJ & $5.267 \mathrm{iJ}$ \\
\hline \multicolumn{5}{|c|}{2009 Season } \\
\hline E.Yasmin & $9.900 \mathrm{ab}$ & $10.11 \mathrm{a}$ & $9.056 \mathrm{abc}$ & $7.651 \mathrm{~d}-\mathrm{i}$ \\
\hline IR77510 & $8.653 \mathrm{~b}-\mathrm{e}$ & $9.639 a b$ & $7.722 \mathrm{c}-\mathrm{h}$ & $6.061 \mathrm{Jk}$ \\
\hline IR78530 & $6.961 \mathrm{f}-\mathrm{J}$ & $8.911 \mathrm{a}-\mathrm{d}$ & $7.028 \mathrm{f}-\mathrm{J}$ & $5.510 \mathrm{k}$ \\
\hline IR74052 & $7.858 \mathrm{c}-\mathrm{g}$ & $7.917 \mathrm{c}-\mathrm{f}$ & $6.500 \mathrm{~g}-\mathrm{k}$ & $5.410 \mathrm{k}$ \\
\hline IR71137 & $7.133 \mathrm{f}-\mathrm{J}$ & $9.539 a b$ & $7.611 \mathrm{~d}-\mathrm{i}$ & 6.294 iJk \\
\hline IR65610 & 7.400 e-J & $8.011 \mathrm{cdef}$ & 6.389 hiJk & $5.187 \mathrm{k}$ \\
\hline
\end{tabular}

Means of each factor designated by the same letter are not significantly different at $5 \%$ level using Duncan's Multiple Range Test. 


\section{1-10- Test of aroma:}

According to aroma test, the date in table (16) showed that Egyptian Yasmin variety was strong in aroma in April $24^{\text {th }}$ and May $24^{\text {th }}$, while it decreasing in late sowing dates (May $24^{\text {th }}$ and June $10^{\text {th }}$ ). On the other hand, IR77510-88-1-3-3 and IR78530-45-3-1-3 were the same trend in early and late sowing dates. IR74052-177-3-3 and IR65610-38-2-4-2-6-3 were not affected by early and late sowing dates. Finally, IR71137-51-2 variety was strongly scented in optimum sowing dates. The conclusion that May $10^{\text {th }}$ was the optimum sowing date of rice under Egyptian condition and the scented aromatic was strongly in optimum sowing, while the early and late sowing it will be decreasing in this characters Table (16). This due to the differences in temperature between day and night during filling period Table2 (16.7Co and 13.4 Co in 2008 and 2009 respectively) as well as relative humidity 69.6 and 66.3 in 2008 and 2009 respectively.

Table (16): Aromatic evaluation (reaction) for the tested varieties under different dates of sowing during the two seasons.

\begin{tabular}{|l|c|c|c|c|}
\hline \multirow{2}{*}{ Variety } & \multicolumn{4}{c|}{ Sowing date } \\
\cline { 2 - 5 } & April 24 & May 10 & May 24 $^{\text {th }}$ & June 10 $^{\text {th }}$ \\
\hline E.Yasmin & \multicolumn{4}{|c|}{ Scent score } \\
IR77510 & 2 & 2 & 1 & 1 \\
IR78530 & 1 & 2 & 1 & 1 \\
IR74052 & 1 & 2 & 1 & 1 \\
IR71137 & 1 & 1 & 1 & 1 \\
IR65610 & 1 & 2 & 1 & 1 \\
\hline
\end{tabular}

\section{2-Mean performance:}

\section{2-1- Under first sowing date (April $24^{\text {th }}$ )}

Results in Table (17) showed that Egyptian Yasmin and IR77510 were high in grain yield $\left(8.75\right.$ and $\left.8.39 \mathrm{t} \mathrm{ha}^{-1}\right)$. These varieties had also high in straw yield and number of field grain per panicles and produced more dry matter per $\mathrm{m}^{2}$ and LAI.

Table (17): Mean performance and variance for six varieties under first sowing date (Average of two years).

\begin{tabular}{|l|c|c|c|c|c|c|c|c|c|}
\multicolumn{1}{c}{ Sowing. } \\
\hline Variety & L.A.I & D. M. & P. H. & No.T. & S.Y. & G.Y. & $\mathbf{1 0 0 0 g}$ & No.G. & No.P. \\
\hline E.Yasmin & 5.945 & 911.5 & 109.5 & 469.5 & 12.97 & 8.75 & 34.65 & 161.0 & 454.5 \\
IR77510 & 5.855 & 897.0 & 111.4 & 449.5 & 13.1 & 8.39 & 22.41 & 147.0 & 438.5 \\
IR78530 & 5.570 & 855.0 & 110.5 & 453.5 & 12.56 & 7.03 & 24.94 & 139.5 & 447.0 \\
IR74052 & 5.520 & 857.5 & 126.5 & 395.5 & 12.95 & 7.22 & 23.76 & 144.5 & 382.5 \\
IR71137 & 5.130 & 805.0 & 121.0 & 359.5 & 11.23 & 7.23 & 23.78 & 142.5 & 348.5 \\
IR65610 & 5.130 & 800.5 & 104.0 & 416.5 & 10.61 & 7.20 & 24.61 & 133.0 & 704.5 \\
Std. Dev. & 1.904 & 45.67 & 8.29 & 41.52 & 1.05 & 0.74 & 4.48 & 9.38 & 125.6 \\
Variance & 4.692 & 854.5 & 113.8 & 424.0 & 12.24 & 7.64 & 25.69 & 144.6 & 462.6 \\
\hline
\end{tabular}

L.A.I: Leaf Area Index $\quad$ D.M.: Dry matter accumulation $\mathbf{g ~ m}^{-2}$ P.H.: Plant height cm No. T.: Number of tillers $\mathrm{m}^{-2}$ S.Y.: Straw yield $\mathrm{t}$ ha-1 11000g: 1000 grain weight $g$ No.G.: Number of filled grains panicle ${ }^{-1}$ G.Y.: Grain yield $t$ ha No.P.: Number of panicle $\mathrm{m}^{2}$ 


\section{2-2- Under second sowing date (May $10^{\text {th }}$ )}

Data in Table (18) show that grain yield ranged from $7.45 \mathrm{t} \mathrm{ha}^{-1}$ to $9.28 \mathrm{t} \mathrm{ha}^{-1}$, where Egyptian Yasmin produced the highest grain yield followed by IR77510, IR71137 and IR78530 respectively. Also, these varieties were superior in L.A.I , dry matter $\left(\mathrm{g} \mathrm{m}^{-2}\right)$, number of tillers $\mathrm{m}^{-2}$, number. of grains/panicle and number of panicles $\mathrm{m}^{-2}$. Such difference could be attributed to genetic variability among rice varieties under study.

Table (18): Mean performance and variance for seven varieties under second sowing date (Average of two years).

\begin{tabular}{|l|c|c|c|c|c|c|c|c|c|}
\hline Variety & L.A.I & D. M. & P. H. & No.T. & S.Y. & G.Y. & 1000g & No.G. & No.P. \\
\hline E.Yasmin & 6.12 & 934.5 & 105.9 & 522.0 & 12.04 & 9.28 & 24.06 & 148.5 & 509.5 \\
IR77510 & 6.22 & 940.5 & 103.0 & 548.5 & 12.73 & 8.95 & 24.32 & 127.5 & 535.5 \\
IR78530 & 6.07 & 916.5 & 113.1 & 547.0 & 11.76 & 8.22 & 24.3 & 126.0 & 538.5 \\
IR74052 & 5.83 & 895.0 & 118.2 & 509.0 & 12.15 & 7.45 & 23.10 & 129.0 & 494.5 \\
IR71137 & 6.05 & 904.0 & 115.7 & 524.5 & 11.97 & 8.56 & 24.42 & 134.0 & 505.0 \\
IR65610 & 5.50 & 849.0 & 108.3 & 497.5 & 10.26 & 7.63 & 24.66 & 126.0 & 479.5 \\
Std. Dev. & 0.26 & 22.12 & 5.92 & 20.29 & 0.83 & 0.72 & 0.55 & 8.69 & 23.05 \\
Variance & 5.97 & 906.6 & 110.7 & 524.7 & 11.82 & 8.35 & 24.14 & 131.8 & 510.4 \\
\hline
\end{tabular}

L.A.I: Leaf Area Index $\quad$ D.M.: Dry matter accumulation $\mathbf{g ~ m}^{-2}$

P.H.: Plant height $\mathrm{cm} \quad$ No. T.: Number of tillers $\mathrm{m}^{-2} \mathrm{~S}$.Y.: Straw yield $\mathrm{t}$ ha-1

G.Y.: Grain yield $t$ ha $^{-1}$

1000g: 1000 grain weight $g$ No.G.: Number of filled grains panicle ${ }^{-1}$

No.P.: Number of panicle $\mathrm{m}^{2}$

\section{2-3- Under third sowing date (May 24th)}

Results in Table (19) show that grain yield ranged from $6.09 \mathrm{t} \mathrm{ha}^{-1}$ to $7.76 \mathrm{t} \mathrm{ha}^{-1}$ and the highest values $\mathrm{t} \mathrm{ha}^{-1}\left(7.76,6.92\right.$ and $\left.6.77 \mathrm{t} \mathrm{ha}^{-1}\right)$ were recorded with Egyptian Yasmin, IR77510 and IR71137, respectively. High yield of these varieties is attributed to high values of dry matters $\left(\mathrm{g} \mathrm{m}^{-2}\right)$, leaf area index and number of tillers $\mathrm{m}^{-2}$.

Table (19): Mean performance and variance for seven varieties under third sowing date (Average of two years).

\begin{tabular}{|l|c|c|c|c|c|c|c|c|c|}
\hline Variety & L.A.I & D. M. & P. H. & No.T. & S.Y. & G.Y. & 1000g & No.G. & No.P. \\
\hline E.Yasmin & 5.39 & 831.0 & 92.1 & 475.5 & 11.04 & 7.76 & 24.22 & 138.5 & 461.5 \\
IR77510 & 5.46 & 843.5 & 96.2 & 528.5 & 10.96 & 6.92 & 24.11 & 120.0 & 517.0 \\
IR78530 & 5.22 & 809.5 & 100.4 & 507.0 & 10.31 & 6.21 & 23.14 & 122.0 & 497.5 \\
IR74052 & 5.15 & 801.5 & 99.4 & 463.5 & 11.26 & 6.11 & 23.08 & 117.0 & 456.0 \\
IR71137 & 5.35 & 829.5 & 103.4 & 451.0 & 11.96 & 6.77 & 22.16 & 127.0 & 445.5 \\
IR65610 & 4.85 & 761.0 & 92.6 & 453.5 & 9.76 & 6.09 & 23.51 & 96.0 & 441.5 \\
Std. Dev. & 0.22 & 29.58 & 4.53 & 31.36 & 0.77 & 0.65 & 0.76 & 14.00 & 30.48 \\
Variance & 5.24 & 812.7 & 97.33 & 479.8 & 10.89 & 6.64 & 23.37 & 120.1 & 469.8 \\
\hline
\end{tabular}

L.A.I: Leaf Area Index $\quad$ D.M.: Dry matter accumulation $\mathbf{g ~ m}^{-2}$ P.H.: Plant height $\mathrm{cm}$

No. T.: Number of tillers $\mathrm{m}^{-2}$ S.Y.: Straw yield $\mathrm{t}$ ha-1 $\quad$ G.Y.: Grain yield $\mathrm{t} \mathrm{ha}^{-1}$

$1000 \mathrm{~g}$ : 1000 grain weight $\mathrm{g}$ No.G.: Number of filled grains panicle ${ }^{-1}$

No.P.: Number of panicle $\mathrm{m}^{2}$

2-4- Under fourth sowing date (June $10^{\text {th }}$ )

The results in Table (20) revealed that grain yield $\mathrm{t} \mathrm{ha}^{-1}$ ranged from $5.22 \mathrm{t} \mathrm{ha}^{-1} \mathrm{t} \mathrm{ha}^{-1}$ to $6.82 \mathrm{t} \mathrm{ha}^{-1}$ and the highest values (6.82, 5.89 and $5.68 \mathrm{t}$ ha $^{-1}$ ) were recorded with Egyptian Yasmin, IR77510 and IR71137, 
respectively. Generally, late sowing dates were effected reduction for all characters of rice varieties under this study.

Table (20): Mean performance and variance for seven varieties under fourth sowing date (Average of two years).

\begin{tabular}{|l|c|c|c|c|c|c|c|c|c|}
\hline Variety & L.A.I & D. M. & P. H. & No.T. & S.Y. & G.Y. & 1000g & No.G. & No.P. \\
\hline E.Yasmin & 4.86 & 762.5 & 84.8 & 432 & 9.96 & 6.82 & 22.80 & 127.0 & 419.5 \\
IR77510 & 4.85 & 765.0 & 91.2 & 446 & 10.49 & 5.89 & 21.68 & 107.0 & 429.0 \\
IR78530 & 4.57 & 725.5 & 99.1 & 425 & 9.13 & 5.25 & 22.97 & 110.0 & 408.5 \\
IR74052 & 4.53 & 714.0 & 93.9 & 401 & 9.60 & 5.40 & 20.75 & 109.5 & 387.0 \\
IR71137 & 4.69 & 743.0 & 91.0 & 416 & 10.44 & 5.68 & 21.38 & 109.5 & 400.0 \\
IR65610 & 4.36 & 692.0 & 82.2 & 415 & 8.80 & 5.22 & 21.05 & 77.5 & 407.0 \\
Std. Dev. & 0.20 & 28.60 & 6.13 & 15.55 & 0.69 & 0.60 & 0.92 & 16.07 & 14.68 \\
Variance & 4.64 & 733.7 & 90.34 & 422.5 & 9.74 & 5.71 & 21.77 & 106.8 & 408.5 \\
\hline
\end{tabular}

L.A.I: Leaf Area Index $\quad$ D.M.: Dry matter accumulation $\mathbf{g ~ m}^{-2}$ P.H.: Plant height cm

No. T.: Number of tillers $\mathrm{m}^{-2}$ S.Y.: Straw yield $\mathrm{t}$ ha-1

1000g: 1000 grain weight $g$ No.G.: Number of filled grains panicle-1

No.P.: Number of panicle $\mathrm{m}^{2}$

\section{3- Yield Reduction (t ha-1)}

Data in Table (21) indicate that grain yield reduction under May $24^{\text {th }}$ ranged from 1.34 to $2.03\left(\mathrm{t} \mathrm{ha}^{-1}\right)$. On the other hand, yield reduction under June $10^{\text {th }}$ ranged from 2.05 to $3.06\left(\mathrm{t} \mathrm{ha}^{-1}\right)$. Egyptian Yasmin varieties less achieving yield reduction, while IR77510 and IR78530 were mach recorded yield reduction under May $24^{\text {th }}$ and June $10^{\text {th }}$. The results revealed that Egyptian Yasmin varieties is not effected by late sowing dates and consider from non photosensitive varieties. While, IR77510 and IR78530 were effected by late sowing dates and consider from photosensitive varieties.

Table (21): Grain yield and yield reduction $\mathrm{t} \mathrm{ha}^{-1}$ of rice varieties as affected by different sowing dates in the two seasons.

\begin{tabular}{|c|c|c|c|c|c|c|c|}
\hline \multirow{2}{*}{ Variety } & \multicolumn{4}{|c|}{ Yield $\left(t h^{-1}\right)$} & \multicolumn{3}{|c|}{$\begin{array}{c}\text { Yield } \\
\text { Reduction }\left(\mathrm{t} \mathrm{ha}^{-1}\right)\end{array}$} \\
\hline & $\begin{array}{l}\text { April } \\
24^{\text {th }}\end{array}$ & May $10^{\text {th }}$ & May $24^{\text {th }}$ & $\begin{array}{c}\text { June } \\
10^{\text {th }}\end{array}$ & April 24 ${ }^{\text {th }}$ & May $24^{\text {th }}$ & June $10^{\text {th }}$ \\
\hline Egyptian Yasmin & 8.75 & 9.29 & 7.76 & 6.83 & 0.54 & 1.53 & 2.46 \\
\hline IR77510 & 8.39 & 8.95 & 6.93 & 5.90 & 0.65 & 2.03 & 3.06 \\
\hline IR78530 & 7.03 & 8.22 & 6.21 & 5.26 & 1.19 & 2.01 & 2.97 \\
\hline IR74052 & 7.23 & 7.46 & 6.12 & 5.41 & 0.23 & 1.34 & 2.05 \\
\hline IR71137 & 7.23 & 8.57 & 6.77 & 5.68 & 1.34 & 1.80 & 2.89 \\
\hline IR65610 & 7.20 & 7.64 & 6.09 & 5.23 & 0.44 & 1.54 & 2.41 \\
\hline
\end{tabular}

4-Clustering of the varieties based on similarity of agronomic characters:

4-1- At first sowing dates (April 24 ${ }^{\text {th }}$ ):

Clustering of varieties based on their performance at first dates produced two large groups of varieties; the first group included IR65610, IR71137 and IR 74052 which were the similar in grain yield and LAI (Fig.1). Meanwhile, the second group included Egyptian Yasmin, IR77510 and IR78510, which were the same in plant height, number of tillers $\mathrm{m}^{-2}$ and number of panicle $\mathrm{m}^{-2}$. 


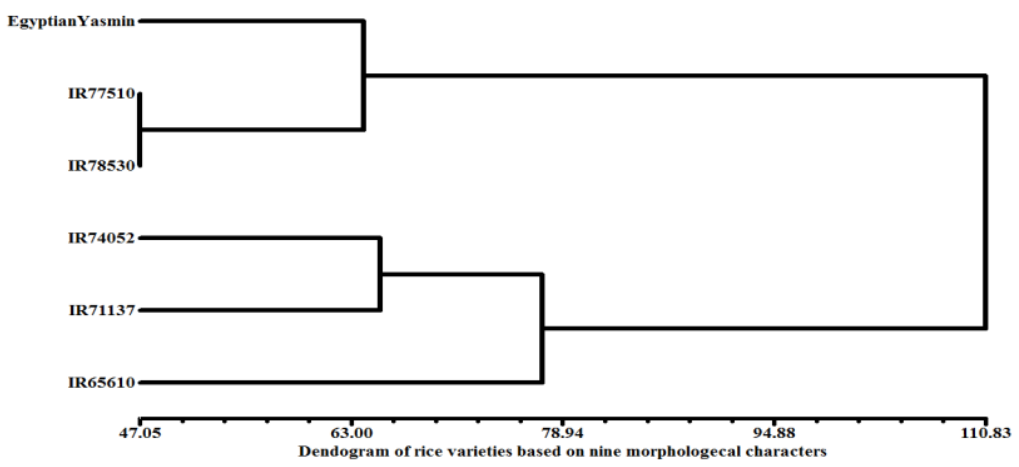

Fig.1. Cluster diagram for six rice varieties classified by nine morphological quantitative characters under first sowing dates (April 24 ${ }^{\text {th }}$ ).

\section{4-2- Under second sowing dates (May $10^{\text {th }}$ ):}

Clustering of varieties based on second sowing dater performance generated two groups (Fig. 2). The first one included IR65610 only, which was leas one in LAl, number of tillers $/ \mathrm{m} 2$ and number of panicle $/ \mathrm{m} 2$. While, the second large group was included Egyptian Yasmin, IR74052, IR71137, IR77510 and IR78530. This group was divided into two sub-groups; the first one included IR77510 and IR78530 varieties together because of their similarity in LAI, dry matter, number of tillers $\mathrm{m}^{-2}, 1000$ - grain weight, number of filled grains per panicle and number of panicles $\mathrm{m}^{-2}$. While, the second sub-group included Egyptian Yasmin in branch alone, which was higher one in grain yield and number of filled grain per panicle. The second branch included IR74052 and 71137 varieties together because of their similarity in plant height character (Fig. 2).

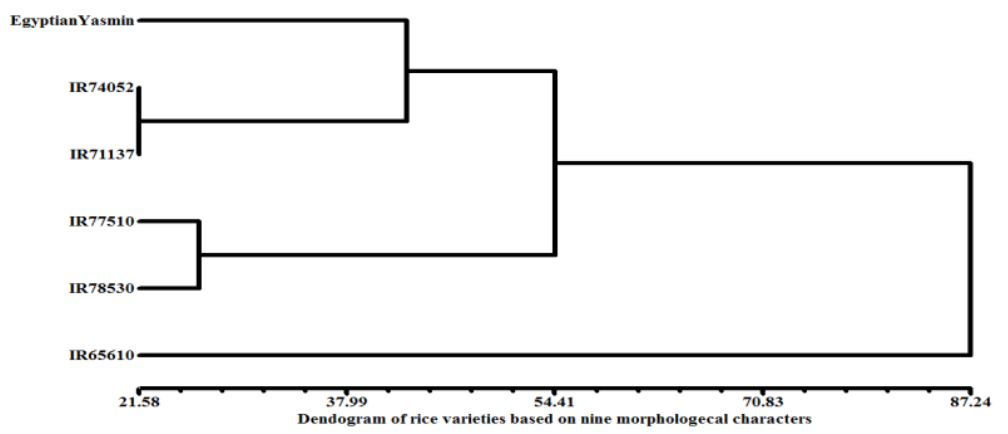

Fig.2. Cluster diagram for six rice varieties classified by nine morphological quantitative characters under second sowing dates (May $10^{\text {th }}$ ).

4-3- Under third sowing date ( $24^{\text {th }}$ May):

Fig. 3 shows that clustering of six classified into two groups, the first one included IR77510 and IR78530 were in the same trend in number of 
tillers $\mathrm{m}^{-2}$ and number of panicles $\mathrm{m}^{-2}$. While, the second group included Egyptian Yasmin, IR71137, IR74052 and IR65610. This group divided into two sub-group, IR65610 in one branch alone because it had less one in LAI, dry matter, straw yield and number of filled grain per panicle. The second sub-group included the other varieties Egyptian Yasmin, IR71137 and IR74052 were high in straw yield.

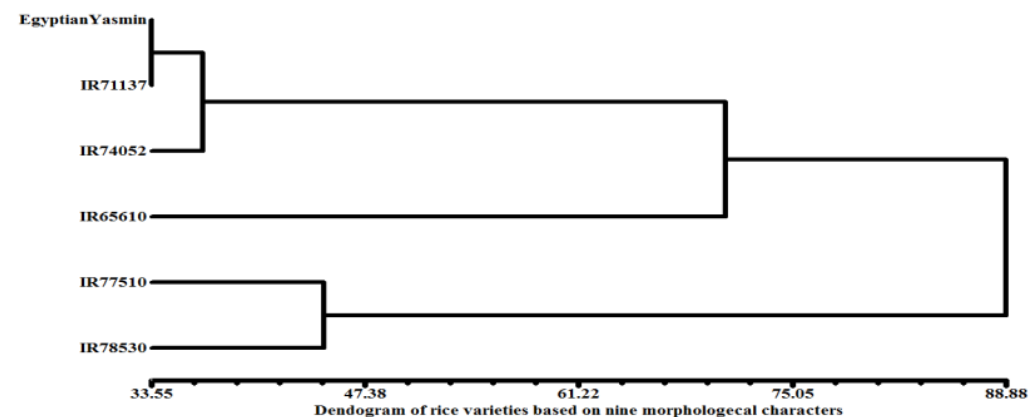

Fig.3. Cluster diagram for six rice varieties classified by nine morphological quantitative characters under third sowing dates (May 24 ${ }^{\text {th }}$ ).

4-4- Under fourth sowing date (June $10^{\text {th }}$ ):

Clustering of varieties based on quantitative characters in June $10^{\text {th }}$ Fig.4 shows that clustering divided into two large groups. The first large group included IR65610, IR74052, IR71137 and IR78530 and divided into two subgroup IR65610 variety in branch alone due to leas than all variety in LAI, dry matter, plant height, straw yield and number of filled grains per panicle. While, the second sub-group included IR74052, IR71137 and IR78530, which were similar in LAl, dry matter, number of tillers $\mathrm{m}^{-2}$ and number of filled grains per panicle. On the other hand, the second group included the two varieties; Egyptian Yasmin and IR77510 were heights in LAl, dry matter number of tillers $\mathrm{m}^{-2}$, grin yield and number of panicles $\mathrm{m}^{-2}$.

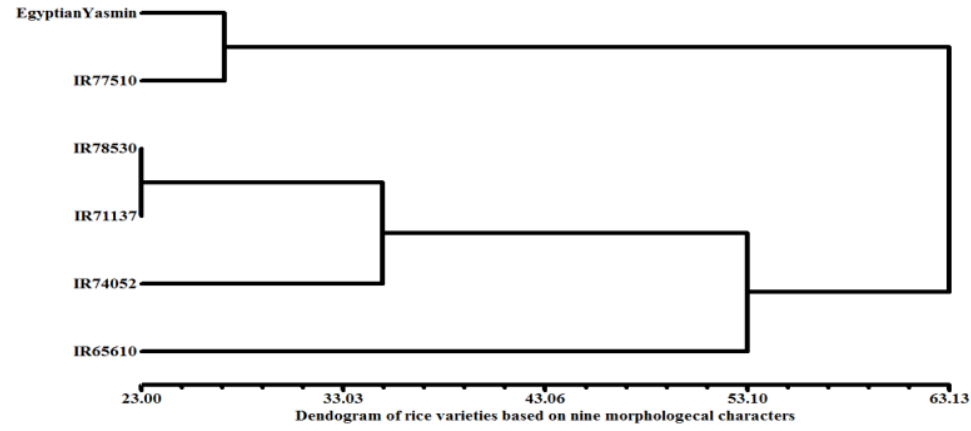

Fig.4. Cluster diagram for six rice varieties classified by nine morphological quantitative characters under fourth sowing dates (June $10^{\text {th }}$ ). 


\section{5- Estimates of correlation coefficient (CC):}

Correlation coefficients were estimated among six varieties for nine agronomic characters listed in (Table 22). Leaf Area Index had highly significant positive correlations with number of tillers $\mathrm{m}^{-2}$. Also, dry matter accumulation $\mathrm{g} \mathrm{m}^{-2}$, had highly significant positive correlations with plant height, number of tillers $\mathrm{m}^{-2}$, Straw yield $\mathrm{t} \mathrm{ha}^{-1}$, number of panicles per plant, panicle length and significant with panicle weight. While, plant height was highly significantly positive correlated with Straw yield $t \mathrm{ha}^{-1}$, grain yield and number of filled grains per panicle. On the other hand, number of tillers $\mathrm{m}^{-2}$ was highly significant positive with grain yield and number of panicles $\mathrm{m}^{-2}$, while straw yield $t \mathrm{ha}^{-1}$ had highly significant positive with grain yield $\mathrm{t} \mathrm{ha}^{-1}$ and number of grains per panicle and significant with 1000 grain weight. Grain yield had highly significant positive with 1000 grain weight and number of grains per panicle and significant positive with number of panicles $\mathrm{m}^{-2}$. Finally, 1000 grain weight was highly significant positive with number of grains per panicle. These results are in agreement with Roy and Kar (1992), Abd El-Aty et al. (2002), and Abd Allah et al. (2005).

Table (22): Correlation coefficient among vegetative studied characters.

\begin{tabular}{|l|c|c|c|c|c|c|c|c|c|}
\hline Character & L.A.I & D. M. & P. H. & No.T. & S.Y. & G.Y. & $\mathbf{1 0 0 0 g}$ & No.G. & No.P. \\
\hline L.A.I & 1.00 & 0.317 & 0.191 & $0.420^{*}$ & 0.126 & 0.261 & 0.365 & 0.141 & 0.293 \\
\hline D. M. & & 1.00 & $0.672^{* *}$ & $0.684^{\star *}$ & $0.866^{* *}$ & $0.936^{* *}$ & $0.514^{*}$ & $0.751^{* *}$ & $0.420^{*}$ \\
\hline P. H. & & & 1.00 & 0.110 & $0.723^{* *}$ & $0.566^{* *}$ & 0.342 & $0.689^{* *}$ & 0.091 \\
\hline No.T. & & & & 1.00 & 0.332 & $0.569^{\star *}$ & 0.239 & 0.161 & $0.545^{\star *}$ \\
\hline S.Y. & & & & & 1.00 & $0.773^{* *}$ & $0.465^{*}$ & $0.799^{* *}$ & 0.162 \\
\hline G.Y. & & & & & & 1.00 & $0.552^{* *}$ & $0.787^{* *}$ & $0.417^{*}$ \\
\hline $\mathbf{1 0 0 0 g}$ & & & & & & & 1.00 & $0.611^{* *}$ & 0.223 \\
\hline No.G. & & & & & & & & 1.00 & 0.183 \\
\hline No.P. & & & & & & & & & 1.00 \\
\hline
\end{tabular}

L.A.I: Leaf Area Index D.M.: Dry matter accumulation $\mathbf{g ~ m}^{-2} \quad$ P.H.: Plant height $\mathbf{~ c m ~}$ No. T.: Number of tillers $\mathrm{m}^{-2}$ S.Y.: Straw yield $\mathrm{t}$ ha-1 1000g: 1000 grain weight $g$ No.G.: Number of filled grains panicle ${ }^{-1}$ No.P.: Number of panicle $\mathrm{m}^{2}$

This positive correlation might indicate the presence of loci, controlling these traits, on the same linkage group and consequently it might be used for early marker assisted selection (EL-Malky 2004).

\section{CONCLUSION}

The results of the present study demonstrated that Aromatic rice varieties varied significantly in most measurements of growth, grain yield and yield attributes, in both seasons. Plants of the Egyptian Yasmin variety having the highest values in the most mentioned traits among the other tested varieties in the two seasons. It can be concluded that the optimum sowing date of Egyptian Yasmin variety is April $24^{\text {th }}$ and May $10^{\text {th }}$ while, sowing date of May $10^{\text {th }}$ is the one optimum for IR 77510, IR 78530 and IR 71137 . Generally aromatic varieties i.e. Egyptian Yasmin, IR77510-88-1-3-3, 
IR78530-45-3-1-3, IR 74052-177-3-3, IR 71137-51-2 and IR65610-38-2-4-26-3 could be recommended to be sown in April $24^{\text {th }}$ and May $10^{\text {th }}$.

\section{REFERANCES}

Abd Allah, A.A., R.N. Gorgy and B.A.Zayed. (2005). Screening some rice genotypes (Oryza sativa L.) under drought conditions. J. Agric. Res., Tanta Univ., 31 (2) 2005

Abd El-Aty, M.S., A.B. El-Abd and A.A. Abd Allah. (2002). Genetic analysis of quantitative traits in rice. J Agric. Sci. Mansoura Univ., 27 (7): 4399 4408

Akhter. M., M. Ahmad and M. Ramzan. (2007). Effect of photoperiod sensitivity on yield and other economic traits of new strains of basmati rice (Oryza Sativa L.). J. Anim. PI. Sci. 17(3-4):79-82.

Akram, H.M., A. Ali, M. A. Nadeem and M. Sarfraz. (2007). Yield and yield components of rice varieties as affected by transplanting dates. Iqbal. J. Agric. Res. 45(2): 105-111.

Ashrafuzzaman, M., M.R. Islam, M.R. Ismail, S.M. Shahidullah and M.M. Hanafi, (2009). Evaluation of six aromatic rice varieties for yield and yield contributing characters. Int. J. Agric. Biol., 11: 616-620.

Aslam, M. (2000). Effect of seeding density and planting time of agrophysiological traits of direct seeded rice (Oryza sativa L.). Ph.D. Thesis, Agron., U.A., Faisalabad.

Bahraman, N., J. L. Gouis, D. Hariri, L. Guilbaud and L. Jestin. (1999). Genetic diversity of old French six-rowed winter barley cultivars assessed with molecular, biochemical and morphological markers and its relation to BaMMV resistance. Heredity, $83: 568-574$.

Dingkhun, M. and F. Asch. (1999). Phenological responses of Oryza sativa, $O$. glaberrima and inter-specific rice varieties on a toposquence in West Africa. Euphytica, 110: 109-126.

Dixit, A.J., V.V. Gaikwad, M.G. Jadhav and S.T. Thorat. (2004). Effect of sowing times on the phenology and growth of hybrid rice parents .J. of Agrometeorology. 2004, 6(Special Issue): 72-76.

Duncan, D.B. (1955). Multiple Range and Multiple F. Test. Biometrics. 11: 1 42.

El-Malky, M.M. (2004). Genetic studies on blast disease resistance in rice (Oryza sativa L.). Ph.D. Thesis, Fac.of Agric. Menofiya Univ.

Ganajaxi, H.D.Mohankumar, Y.Hegde and V.V.Angadi. (2001). Effect of planting dates and $\mathrm{N}$ Levels on the grain yield of aromatic rice varieties under rainfed conditions. Karnataka J. Agric. Sci., Univ. Agric. Sci. Dharwad, India..14(3):758-759.

Ghosh. M., B. K. Mandal, B. B. Mandal, S. B. Lodh and A. K. Dash. (2004). The effect of planting date and nitrogen management on yield and quality of aromatic rice. J. Agric. Sci., 142, 183-191.

Gomez K. and A. Gomez. (1984). Statistical Procedures of Agricultural Research. John Wiley and Sons. Inc., New York, U.S.A. 
Habibullah., N. H. S. , A. Nazir and F. lqbal. (2007). Response of rice varieties to various transplanting dates. Pak. J. Pl. Sci., 13 (1): 1-4.

Hossain, M.B., M.O. Islam and M. Hasanuzzaman. (2008). Influence of different nitrogen levels on the performance of four aromatic rice varieties. Int. J. Agric. Biol., 10(6): 693-696.

IRRI.(1996). Standard Evaluation System for rice SES. International Rice Research Institute. Los Banos, Philippines.

Islam, M.S., M.A. Hossain, M.A.H. Chowdhury and M.A. Hannan. (2008). Effect of nitrogen and transplanting date on yield and yield components of aromatic rice. J. Bangladesh Agric. Univ. 6(2): 291-296

Latif A. (2005). Modelling the growth, radiation use efficiency and yield of fine rice (Bas-2000) as affected by sowing dates and time of nitrogen application. M. Sc. Thesis. Dept. of Agron. Univ. Agric. Faisalabad, Pak.

Lee, K.S. and J.H. Jun. (1998). Identifying optimum seeding time for direct seeding. Int. Rice Res. Newsl. 23(2): 29-30.

Linscombe, S.D., D.L. Jordan, A.B. Burns and R.P. Viator. (2004). Rice response to planting date differs at two locations in. CropManagement.(January):1-7.

Lu-Kaiyang and Cai-Mingli. (2000). Characteristics of growth and development and high yield cultivation technology in intermediate season hybrid rice 11 you 501. J. Huazhong Agric. Univ. 19:2, 91-94.

Mahmood, N., A. Hussain, B. Akhtar, A.H. Ahmad and M. Saleem. (1995). Effect of transplanting date and irrigation on rice paddy yield. Sci. Tech. \& Development, 14(3): 49-52.

Mannan, M.A., M.S.U. Bhuiya, S.M.A. Hossain and M.I.M. Akhand. (2009). Study on phenology and yielding ability of basmati fine rice genotypes as influenced by planting date in aman season. Bangladesh J. Agric. Res. 34(3) : 373-384.

Mondal, M.M.A., A.F.M. Islam and M.A. Siddique. (2005). Performance of 17 modern transplant aman cultivar in the northern region of Bangladesh. Bangladesh J. Crop Sci., 16: 23-29

Safdar, M. E., A. Amjed, M. Sher, S. Ghulam and H. A. Tahir. (2008). Effect of transplanting dates on paddy yield of fine grain rice genotypes. Pak. J. Bot., 40(6): 2403-2411.

Nahar, K., H. Mirza and R. R. Majumder. (2009). Effect of low temperature stress in transplanted aman rice varieties mediated by different transplanting dates. Acad. J. Plant Sci., 2 (3): 132-138.

Nayak, B.C., B.B. Dalei and , B.K.Chodhury, (2003). Response of hybrid rice to date of planting, spacing and seedling rate during wet season. Indian J. Agron., 48 (3) : 172-174.

Reddy, K.S. and B.B. Reddy. (1992). Effect of transplanting time, plant density and seedling age on growth and yield of rice. Indian J. Agron., 31 (1): 18-21.

Rohlf, F.J. (2000). NTSYS-PC manual Exeter Software, Setauket, New York.

Roy, A. and M.K. Kar. (1992). Heritability and correlation studies in upland rice. Oryza, 29, 195-199 
Sahu, D.K. (1994). Effect of date of transplanting and potassium on growth and yield of lowland rice. Oryza, 31 (1): 38-39.

Shah, L.M. And K.P. Bhurer. (2005). Response of wet seeded rice varieties to sowing dates. Nepal Agric. Res. J. Vol. 6.

Shahidullah, S.M., M.M. Hanafi, M. Ashrafuzzaman, M.R. Ismail and M.A. Salam. (2009). Tillering dynamics in aromatic rice genotypes. Int. J. Agric. Biol., 11: 509-514.

Singh, T., Y.S.Shivay and S.Singh. (2004). Effect of date transplanting and nitrogen on productivity and nitrogen use indices in hybrid and non hybrid aromatic rice. Acta Agronomica Hungaica, 52(3), pp. 245-252.

Souza, E. and M. E. Sorrells. (1991). Relationships among 70 North American Oat germplasms: 1 . Cluster analysis using quantitative characters. Crop Sci. 31: 599-605.

Vandana, J., G.S.B. Ains and H.S. Mavi. (1994). Effect of different dates of transplanting on biomass of production and its partitioning in various parts of rice crop. Indian J.Ecol. 21(1): 13-18 [Rice Absts. 19 (3): 1717, 1996]

Verma, A.K., N, Pandey and R.S. Tripathi. (2004). Leaf growth , chlorophyll, nitrogen content and grain yield of hybrid rice as influenced by planting times and N levels. Annals of Agric. Res. 25(3):456- 458.

Zhang, Q., Y.J. Gao, M.A. Saghai Maroof, S.H. Yang and J.X. Li. (1995). Molecular divergence and hybrid performance in rice. Molecular Breeding, 11: 133-142.

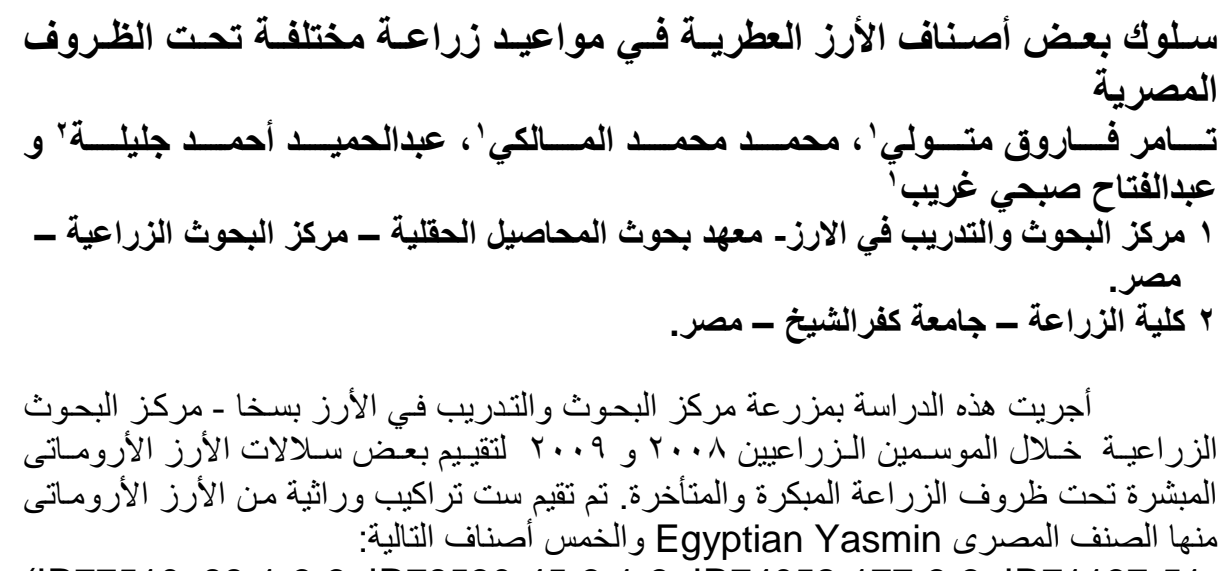

(IR77510-88-1-3-3, IR78530-45-3-1-3, IR74052-177-3-3, IR71137-512, IR65610-38-2-4-2-6-3).

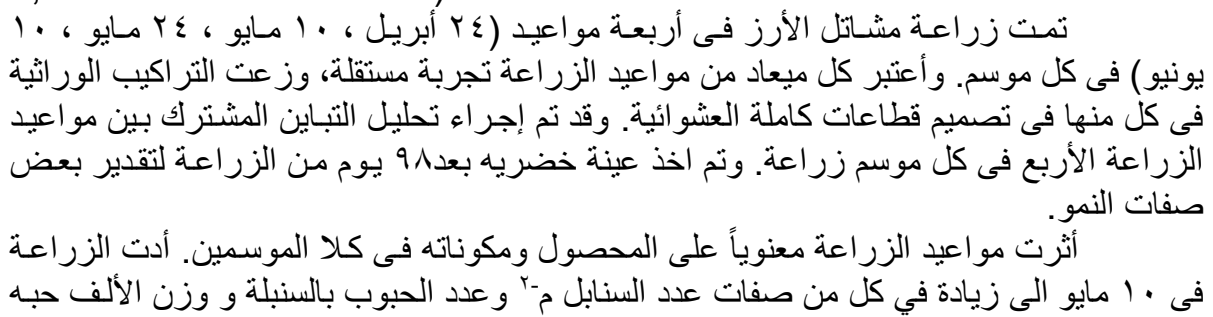


(جم) رحصول الحبوب (طن هكتار -') و محصول القش (طن هكتار -') ونسبة الأروما بالمقارنـة

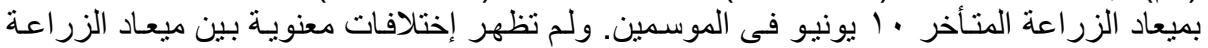

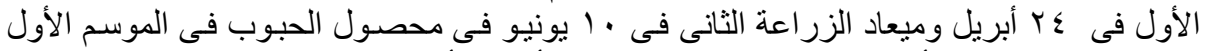

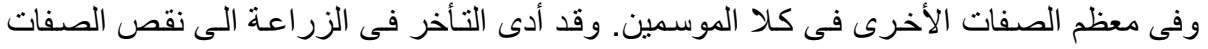

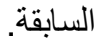

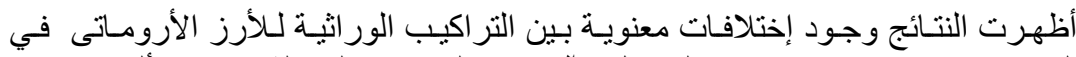

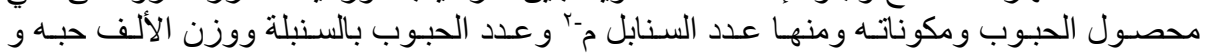

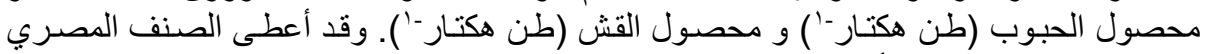

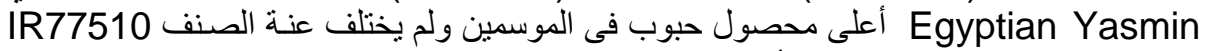
فى محصول الحبوب قى الموسم الأول.

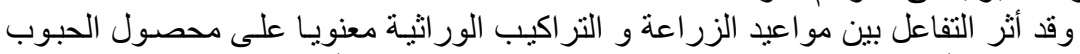

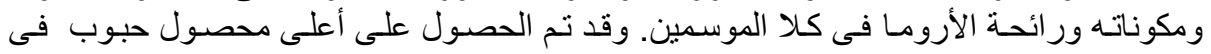

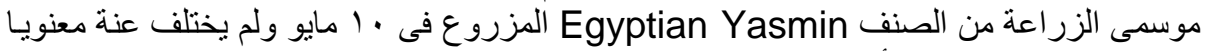

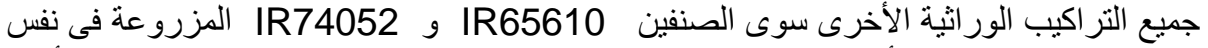
المو عد. و وبو جه عام فقد أنخفض محصول الأخرى الحبوب ومكوناته فى جميع التر اكيب الور اثيـة بتأخير

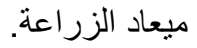

كلية الزراعة - جامعة المنصورة قام بتحكيم البحث

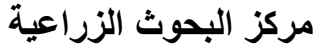

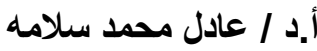
أ.د / أد / عبد السلام عبيد دراز 